\title{
Developing preclinical models of neuroblastoma: driving therapeutic testing
}

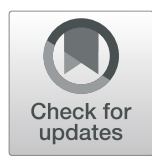

Kimberly J. Ornell and Jeannine M. Coburn ${ }^{*}$ (1)

\begin{abstract}
Despite advances in cancer therapeutics, particularly in the area of immuno-oncology, successful treatment of neuroblastoma (NB) remains a challenge. NB is the most common cancer in infants under 1 year of age, and accounts for approximately $10 \%$ of all pediatric cancers. Currently, children with highrisk NB exhibit a survival rate of $40-50 \%$. The heterogeneous nature of NB makes development of effective therapeutic strategies challenging. Many preclinical models attempt to mimic the tumor phenotype and tumor microenvironment. In vivo mouse models, in the form of genetic, syngeneic, and xenograft mice, are advantageous as they replicated the complex tumor-stroma interactions and represent the gold standard for preclinical therapeutic testing. Traditional in vitro models, while high throughput, exhibit many limitations. The emergence of new tissue engineered models has the potential to bridge the gap between in vitro and in vivo models for therapeutic testing. Therapeutics continue to evolve from traditional cytotoxic chemotherapies to biologically targeted therapies. These therapeutics act on both the tumor cells and other cells within the tumor microenvironment, making development of preclinical models that accurately reflect tumor heterogeneity more important than ever. In this review, we will discuss current in vitro and in vivo preclinical testing models, and their potential applications to therapeutic development.
\end{abstract}

Keywords: Neuroblastoma, Model, Therapeutic, In vitro, In vivo

\section{Background}

Neuroblastoma (NB) is the most common solid, extracranial childhood tumor, accounting for approximately $15 \%$ of all childhood cancer deaths [1-3]. Nearly half of all patients are classified as having high-risk disease, portending poor long-term survival despite multimodal treatment [4]. NB is a disease of the sympaticoadrenal lineage of the neural crest, with tumors forming anywhere in the sympathetic nervous system. The tumors most commonly arise in the abdomen (65\%), however, they also occur in the neck, chest, and pelvis. Approximately $50 \%$ of patients present with evidence of metastasis $[5,6]$. Frequent metastasis sites include cortical bone, bone marrow, liver, and lymph nodes $[5,6]$. The disease exhibits a broad range of clinical behaviors, making treatment difficult, particularly for high-risk patients [1, 4]. NB typically occurs in children who do not have a

\footnotetext{
* Correspondence: jmcoburn@wpi.edu

Department of Biomedical Engineering, Worcester Polytechnic Institute, 100 Institute Road, Worcester, MA 01605, USA
}

family history of the disease, although there are some genetic changes frequently associated with the disease [7]. The most common genetic change is MYCN amplification, which occurs in approximately $20 \%$ of patients, and is strongly correlated with advanced stage NB $[8,9]$. Additionally, deletions of the short arm of chromosome 1 (1p) are found in $25-35 \%$ of patients and can be correlated with MYCN amplification [10-12]. Outside of MYC linked changes, allelic loss of $11 \mathrm{q}$ is present in 35 $45 \%$ of patients and is also associated with high-risk disease features [13, 14].

Treatment strategies for NB are guided by the staging and risk level of the disease. In low risk patients, surgery is frequently curative. Should recurrence of NB occur, it is usually local to the original tumor site and can be managed surgically $[14,15]$. Use of cytotoxic therapies is typically avoided due to the high amount of long-term complications [16]. Treatment for patients with intermediate or high-risk NB consists of a multimodal approach including surgical resection, chemotherapy, and

(c) The Author(s). 2019 Open Access This article is distributed under the terms of the Creative Commons Attribution 4.0 International License (http://creativecommons.org/licenses/by/4.0/), which permits unrestricted use, distribution, and 
radiation [4]. Typical treatment of NB begins with resection of the primary tumor coupled with chemotherapy and radiation to manage the tumor size and facilitate resection $[17,18]$. If the tumor is too large for surgical resection, an initial induction treatment with chemotherapy is utilized to shrink the tumor. Chemotherapies typically used include doxorubicin, vincristine, cisplatin, etoposide, and cyclophosphamide [19]. Stem cell rescue can also be used during the consolidation part of the therapeutic regime after high-dose chemotherapy kills the cells within the bone marrow [20].

There are multiple therapeutics currently undergoing preclinical development or in clinical trials for NB. These therapeutics include cytotoxic agents such as topoisomerase 1 inhibitors, radionuclides, retinoids, angiogenesis inhibitors, and tyrosine kinase inhibitors [21-26]. Recently, immunotherapy has emerged as a promising therapy to improve outcomes in patients with advanced stage $\mathrm{NB}$, specifically targeting the highly expressed disialoganglioside GD2. Currently, monoclonal antibodies for GD2 have been clinically approved for therapy in combination with GM-CSF, IL-2, and 13-cisretinoic acid, while other forms of immunotherapy (e.g. T-cell) are still under development [27-29]. Despite the emergence of novel therapeutics including immunotherapeutics, the prognosis for high-risk patients remains poor.

NB is a heterogeneous cancer, with few distinct subtypes and many different clinical presentations [30]. Development of effective therapeutics is dependent on understanding tumor heterogeneity and the ability to accurately test therapies in a preclinical setting. Preclinical models typically use developed environments (murine or in vitro) to assess how a tumor will respond to therapeutics. The high degree of heterogeneity, lack of consistent genetic markers, and range of prognosis (dependent on stage) makes generating accurate preclinical models difficult. This review highlights current strategies and challenges of in vitro and in vivo NB modeling for preclinical therapeutic testing.

\section{Main text}

\section{Preclinical murine models}

Murine models are frequently used for preclinical testing of therapeutics due to their genetic homology to humans ( 80\%), ability to be genetically manipulated to mimic human diseases, and complex multicomponent environment (e.g stroma, immune cells) [31]. They are advantageous as they provide information regarding therapeutic efficacy that cannot be demonstrated in traditional, less complex in vitro cultures. Murine models are typically a necessary stage before progressing therapies to clinical trials. There are many different types of murine models, including genetically engineered models, spontaneously formed tumors, mice with implanted mouse or human tumors, and, more recently, mixed cell type xenograft models. Each of these models is uniquely suited for preclinical testing of therapeutics. However, there is the still need for further improvement and refinement to drive the development of successful therapeutics.

\section{Transgenic mouse models}

Transgenic mice, also referred to as genetically engineered mouse models (GEMMs), can be engineered through promotion or addition of genes (knock-in) or inhibition of gene expression (knock-out). Methods of GEMM development have been reviewed elsewhere [32, 33]. Table 1 contains a list of currently used GEMMs for NB. The most widely used GEMM researched for NB is the TH-MYCN model developed by Weiss et al. [34]. These mice overexpress MYCN through a tyrosine hydroxylase promoter. This model was the first to demonstrate that MYCN amplification can drive NB development, identifying the MYCN pathway as a potential therapeutic target. Tumors generated from MYCN overexpressing mice have MYCN protein levels similar to that of the established NB KELLY cell line, known to contain amplified MYCN [34]. Additionally, similar histopathology is observed between MYCN-amplified patient tumor samples and TH-MYCN tumors [35]. This model has been used extensively in preclinical testing for small molecule inhibitors and testing of chemotherapeutics [35-41]. MYCN pathway inhibitors that showed success in vitro in MYCN-amplified cell lines, such as bromodomain and extra-terminal domain protein inhibitors and cyclin-dependent kinase inhibitors, demonstrated similar results in the TH-MYCN model [37, 42, 43]. High MYCN expression has been linked to high levels of angiogenesis. TH-MYCN tumors treated with angiogenic inhibitors, such as the angiogenesis inhibitor TNP-470, demonstrated a high level of response. In treated tumors, intact blood vessels were replaced with hemorrhagic areas containing necrosis and apoptosis [35]. This model has also been used, although to a limited extent, for testing immune checkpoint inhibitors [44]. While the TH-MYCN model has been considered the standard for preclinical modeling of MYCNamplified tumors, there are still limitations. There is a high rate of tumor incidence in the 129/SvJ background (100\% for homozygous mice and 33\% for heterozygous mice). However, there is a considerably low rate of tumor incidence in alternative background strains such as BL6 (5\% incidence), making crossing with established BL6 GEMMs a challenge [34]. Additionally, distant metastasis frequently occur in the clinical presentation of MYCN-amplified tumors, but are rarely observed in the TH-MYCN model [52]. This model is also limited by 
Table 1 Table of preclinical genetically engineering murine models

\begin{tabular}{|c|c|c|c|}
\hline Mouse Model & Advantages & Limitations & References \\
\hline TH-MYCN & Representative of high-risk NB, high rate of tumor incidence & $\begin{array}{l}\text { Long time for tumor development, few metastasis, } \\
\text { limited background strain }\end{array}$ & [34-43] \\
\hline $\begin{array}{l}\text { LSL-MYCN; } \\
\text { Dbh-iCre }\end{array}$ & $\begin{array}{l}\text { Better defined transgene insertion then TH-MYCN, high rate of inci- } \\
\text { dence in multiple background strains }\end{array}$ & $\begin{array}{l}\text { Few metastasis, Limited work with preclinical } \\
\text { therapeutic testing }\end{array}$ & [44] \\
\hline $\begin{array}{l}\text { TH-MYCN/ } \\
\text { CASP8(KO) }\end{array}$ & Metastasis, high rate of tumor incidence & Altered ECM structure of primary tumor & [45] \\
\hline $\begin{array}{l}\text { TH-MYCN/ } \\
\text { Trp53(KI) }\end{array}$ & Inducible p53 loss & $\begin{array}{l}\text { p53 mutation more frequently present in } \\
\text { recurrences, survival in mice greatly reduced }\end{array}$ & [46] \\
\hline ALK (F1174) & Consistent with NB phenotype & Only present in $10 \%$ of NB & {$[47,48]$} \\
\hline $\begin{array}{l}\text { TH-MYCN/ } \\
\text { ALK(F1174) }\end{array}$ & High tumor incidence, faster tumor growth & Relevance is limited to $<10 \%$ patients & [48] \\
\hline SV40 Tag & $\begin{array}{l}\text { Consistent with NB phenotype, high tumor incidence rate, } \\
\text { metastasis }\end{array}$ & All mice die by 28 weeks of age & [49-51] \\
\hline
\end{tabular}

the long development time (an average of 65 days), making it difficult for rapid, high-throughput testing [52, 53].

To address some of the limitations of the TH-MYCN model, a mouse with Cre inducible MYCN expression (LSL-MYCN;Dbh-iCre) was created [53]. This model has a better-defined transgene insertion site allowing tumors to develop at multiple locations in the neural crest, such as the adrenals, the celiac ganglia, and the superior cervical ganglia. Additionally, this model allows for tumor development in multiple mouse strain backgrounds, which is important when combining the TH-MYCN mouse with other cancer relevant alleles [53]. LSLMYCN;Dbh-iCre mice recapitulates NB histology and molecular expression patterns [53]. These mice are advantageous compared to TH-MYCN mice as the transgene insertion is localized to the commonly used ROSA26 locus, which, when discontinued, causes no phenotypic change in mice. Alternatively, the $\mathrm{TH}$ MYCN mouse primarily inserts into the distal region of chromosome 18, the effects of which have not fully been characterized. While the insertion site has been changed, MYCN expression increased to comparable levels as the TH-MYCN model. Cell lines derived from the LSL-MYCN;Dbh-iCre mouse also respond to the MYCN targeting drugs MLN8327 and JQ1 [53]. This model presents a more defined MYCN-amplified tumor model for preclinical testing, and could prove useful for future testing of therapies aimed at treating high risk MYCN-amplified NB.

In addition to the LSL-MYCN;Dbh-iCre mouse, the TH-MYCN mouse has been genetically modified to incorporate other oncogenes. A cross of a TH-Cre caspase- 8 knockout mouse with a TH-MYCN mouse exhibited increased bone marrow metastasis as compared to the TH-MYCN mouse (37\% versus $5 \%$ incidence) [45]. Loss of caspase- 8 does not change the incidence of primary tumors, however, it does change the extracellular matrix (ECM) structure of the primary tumor into a more migratory phenotype with increased collagen 4A2 and laminin $\alpha 4$ as well as increased EMT genes (Snai2, Twist1 and TfpI2). The metastatic propensity of this model could be useful for identifying treatments for metastatic NB. In addition, similar to clinical treatment strategies, the primary tumors in the mice could be debulked and allowed to metastasize. This could allow this model to be used to gain knowledge about the metastatic population and identify therapeutic approaches specifically geared towards those tumors [45].

To mimic the impaired p53 function frequently present in high-risk NB recurrence, a TH-MYCN/ $\operatorname{Trp} 53(\mathrm{KI} / \mathrm{KI})$ mouse with a tamoxifen inducible p53ER fusion protein was created [46]. Survival in TH-MYCN/ Trp53(KI/KI) mice reduced, and the tumors exhibited decreased radiosensitivity [46]. In addition, when functional p53 was restored to these mice, only 50\% regained sensitivity to radiation, suggesting other resistance mechanisms. Additionally, the authors determined that the upregulation of the glutathione S-transferase pathway observed in this model was correlated with poor survival in NB patients [46]. TH-MYCN/Trp53(KI/KI) allografted tumors treated with the glutathione $\mathrm{S}$ transferase pathway inhibitor buthionine sulfoximine regained sensitivity to radiation, suggesting a potential therapeutic strategy for patients with MYCN amplification and impaired p53 function [46].

Other mutations have been examined as a method of inducing NB, such as activation of anaplastic lymphoma kinase mutations (ALK), present in approximately $10 \%$ of NB [54]. One model used targeted expression of the most common and aggressive ALK mutation ALK ${ }^{\mathrm{F} 1174}$. This model exhibited a similar phenotype to NB and syntenic changes similar to those present in clinical NB including $17 \mathrm{q}$ gain and $\mathrm{MYCN}$ amplification [47]. Preclinically, this model has been used to evaluate drug response to ALK inhibitors and may provide useful insight into treatments for ALK mutated NB. To provide a 
model comparable to patient tumors that exhibit both MYCN amplification and ALK mutations, the ALK ${ }^{\mathrm{F} 1174}$ mutation model was crossed with TH-MYCN mice [48]. Mice hemizygotic for both $\mathrm{ALK}^{\mathrm{F} 1174 \mathrm{~L}}$ and MYCN amplification exhibited high tumor penetrance with rapid lethality superior to that observed in MYCN hemizygotes allowing for elucidating the interplay between the ALK and MYCN pathways [55].

Finally, a transgenic mouse line carrying tetracycline inducible simian virus $40 \mathrm{~T}$-antigen (SV40 Tag) has been created using tetracycline responsive elements with a cytomegalovirus promoter and SV40 Tag [49]. These mice die by 28 weeks of age and exhibit bilateral adrenal tumors. When compared to both human adrenal NB and pheochromocytoma, higher similarity to human NB tumors was observed compared to the pheochromocytoma. NB-associated genetic changes were present with upregulation of MYCN, paired-like homeobox 2b, gamma-aminobutyric acid A receptor beta3 subunit, islet 1 , and kinesin family member $1 \mathrm{~A}[49,50]$. In addition, when this model was linked to the olfactory marker protein promoter region, it generated a line of mice with highly metastatic tumors originating in the adrenals or sympathetic ganglia. These metastatic tumors were morphologically very similar to clinical NB histologically [51]. While limited preclinical therapeutic testing has been performed with these models, it has the potential to be a promising model for therapeutic testing due to its genetic similarity to $\mathrm{NB}$ and ability to mimic metastasis.

GEMMs are advantageous as they utilize mouse homologs of tumorigenic mutations present in patient tumors to mirror clinical tumors. The mouse retains an intact immune system and stroma, allowing for evaluation of therapeutics that target both the tumor and the surrounding microenvironment. They have specific pathway activations, allowing for analysis and targeted therapeutic testing $[42,48,56]$. The genetic changes are constitutively active in mice throughout development or can be induced at a specific developmental stage. This is important as neuroblastoma arises from developing cells in pediatric patients. In addition, transgenic mice with different allele modifications can be crossed in order to study crosstalk between oncogenic pathways [48]. While GEMMs are useful in understanding tumorigenesis and developing therapeutics, there are some drawbacks to these models. They are time consuming and difficult to generate, and while murine pathways share some homology to human pathways, are not a perfect match to humans [31]. Further, a large number of therapies still exhibit a differential response between murine and clinical models [57]. This may be partially due to a lack of control over the modification (e.g. achieving full knockout) of targeted oncogenes. While more advanced methods such as the CRISPR system have been employed for other cancers and for NB cell lines in vitro, they have yet to be reported on for NB mouse models. In addition, a fundamental problem with many GEMMs is that mutations are frequently not localized to pathological cells and can impact other cells within the mouse [34].

\section{Syngeneic mouse models}

Syngeneic mouse models, also known as allograft tumor models, utilize tumor cells derived from a mouse of the same genetic mouse strain. Tumor cells can be removed from GEMMs, used to develop cell lines in vitro, then reintroduced into mice of the same strain [58-61]. Tumorigenic cells capable of cell line derivation have been identified in TH-MYCN mice as early as day E13.5 [61]. TH-MYCN tumors from both homozygous and hemizygous mice have been used to develop syngeneic tumors. Whether the mouse was homozygous or hemizygous impacted the cell phenotype and allowed for the creation of different tumor lines. Hemizygous tumors gave rise to cell lines which were phenotypically similar to an N-type NB, expressing high levels of MYCN. Homozygous tumors gave rise to cell lines phenotypically comparable those of hemizygous tumors ( $\mathrm{N}$-type high MYCN) and to S-type, adherent NB cells, that exhibited reduced MYCN expression [60]. Interestingly, the cell lines derived from hemizygous tumors also displayed reduced tumorigenicity in a syngeneic model, compared to that of the original tumor phenotype. Further, these cell lines contained many genetic changes present in clinical NB, allowing for syngeneic mice to better represent clinical NB. For example, mouse chromosome homologous to human chromosomes 7 and 12 were gained in one cell line, which has been observed in a subset of clinical cases. Gains homologous to chromosomes $1 \mathrm{q}$ and $18 \mathrm{q}$ were frequently observed in TH-MYCN derived cell lines, further suggesting that molecular and biological features of NB are present in derived murine cell lines [60]. These murine tumor cells can be transplanted into mice of the background strain, leaving an intact matched immune system and stroma [58-60].

TH-MYCN-derived lines have been transplanted into mice both subcutaneously and orthotopically [58-60]. Injection of tumor lines derived from TH-MYCN tumors in a $\mathrm{C} 57 \mathrm{Bl} / 6$ background into $\mathrm{C} 57 \mathrm{Bl} / 6$ mice has been used for preclinical testing of immunotherapies [58]. Kroesen et al. demonstrated the relevance of this model for immunotherapy testing due to the tumors expressing similar surface marker profiles (low HLA molecules and the presence of NKG2D activating ligand Rae1), and containing similar resident immune populations [58]. In addition to TH-MYCN-derived tumors, 
other tumors derived from murine cell lines, such as neuro-2a (spontaneous NB from strain A albino mice, C1300 derived), TBJ (C1300, a strain A/J spontaneous tumor), 9464D (TH-MYCN on a $\mathrm{C} 57 \mathrm{Bl} / 6$ ) and NXS2 (created from C1300 tumors) have been engrafted both subcutaneously and orthotopically for testing of immunotherapeutics [62-64]. In particular, preclinical testing of GD2-targeting immunotherapeutics, both individually and in combination with IL-2, and examining the impact on other immune components has been performed using these models [58, 59, 64-66].

Syngeneic transplantations of murine cells are advantageous as tumorous cells can be engrafted in mice with a non-genetically modified matching immune system and stroma [58, 59]. Unlike transgenic mouse models, the genetic mutations are confined to the transplanted tumor cells. In addition, there are typically an abundance of cells for transplantation, which allows for large scale therapeutic testing [58]. Further genetic modification of cells in vitro can also be performed to either add tumor relevant pathway modifications or to add markers to improve cell visualization such as fluorescent or luciferase labels [63, 67, 68]. Potential modifications to cells will be discussed further in the in vitro model's section. Disadvantages of syngeneic models include inconsistency in tumor engraftment and the use of the murine system. Similar to GEMMs, engrafted tumors are frequently based on a single oncogenic based mutation as compared to the heterogeneity exhibited in clinical tumors [52].

\section{Xenograft models}

Human cells have been engrafted into mice for preclinical testing and understanding mechanisms of NB development. Xenograft models can be generated via subcutaneous or orthotopic injection of human NB cells. Tumors developed in these studies are advantageous compared to those developed in GEMMs or in syngeneic models as they more closely mimic a primary human tumor and are better predictors of clinical outcomes [52]. A table of different human cell lines commonly xenografted into mice can be found in Table 2. Use of cell lines with different genetic profiles allows for the formation of tumors with different phenotypes and growth rates [52,69]. Additionally, these tumors mimic some of the heterogeneity observed in patient tumors [52]. They are typically easier to generate than tumors generated using primary patient-derived cells, and allow for large scale studies, as cell lines can be scaled up in vitro before engraftment. However, they require the use of immunocompromised mice (typically lacking $\mathrm{T}$ cells) for engraftment and survival, which provides a less realistic tumor microenvironment and limits the conclusions that can be made when testing immunotherapies. Both orthotopic and subcutaneous tumors have been used extensively for preclinical testing of therapeutics. Therapeutic testing has extended to chemotherapy, radiotherapy, small interfering RNA, antisense oligonucleotides and pathway inhibitors as well as drug delivery methods such as nanoparticles and drug-loaded scaffolds or films [56, 69, 102-108]. In addition to subcutaneous and orthotopic injection, Seong et al. used intracardiac injection xenograft models to identify NB subpopulations with a higher metastatic potential. Metastatic populations and phenotype differences correlated with genetic changes representing utility for these metastatic cells in identifying new therapeutic targets [109].

Borriello et al. evaluated the impact of the heterogeneous microenvironment. NB cell lines with and without bone marrow-derived mesenchymal stromal cells (BM-

Table 2 Frequently used human NB cells lines for preclinical testing

\begin{tabular}{lllll}
\hline Cell Line & MYCN Status & ALK Mutation & P53 mutation & Preclinical Testing References \\
\hline KELLY & Amplified & WT & WT & {$[69-75]$} \\
CHP-212 & Amplified & WT & WT & {$[76,77]$} \\
SKNAS & Non-Amplified & WT & H168R & {$[76,78-86]$} \\
SH-SY-5Y & Non-Amplified & F1174L & WT & {$[70,71,75,78,87-89]$} \\
IMR-32 & Amplified & WT & WT & {$[80,88,90,91]$} \\
IMR-05 & Amplified & WT & WT & {$[37,86,89,92]$} \\
LA-N-5 & Amplified & R1275Q & WT & {$[71,93,94]$} \\
NB-1 & Amplified & WT; Amplified & WT & {$[95,96]$} \\
SK-N-BE(2) & Amplified & WT & C135F & {$[75,78,83,89,86,97]$} \\
SK-N-BE(2)-C & Amplified & WT & C135F & {$[78]$} \\
CHP-134 & Amplified & WT & WT & {$[78,89,98,99]$} \\
SK-N-DZ & Amplified & WT & R1 & {$[82,84,85]$} \\
NB-1691 & Amplified & WT & WT & {$[83,100,101]$}
\end{tabular}


MSCs) and cancer-associated fibroblasts (CAFs) taken from NB patients were injected subcutaneously and just below the renal capsule [110]. Engrafted tumors were treated with the chemotherapeutics etoposide, etoposide with ruxolitinib (JAK2/STAT3 inhibitor), and trametinib MEK/ERK1/2 (inhibitor). These inhibitors were chosen as CAFs and BM-MSCs have activated STAT3 and ERK1/2 pathways, which contributes to drug resistance. No difference in response to etoposide between NB cells and NB cells with BM-MSCs and CAFs was observed. However, response to etoposide by NB cells and NB cells with BM-MSCs and CAFs was enhanced when combined with ruxolitinib and trametinib. In the NB cell alone tumors, murine CAFs were identified within the tumor, potentially explaining the similarity in response.

While cell lines injected into mice are typically passaged in vitro, many studies have shown that traditional in vitro culture methods significantly impact the cell genotype and phenotype. This may be due to the cells adapting to the tissue culture environment and the lack of in vivo relevant signaling. Instead, cells in tissue culture rely on culture medium, with potential adverse effects, specifically related to fetal bovine serum. Fetal bovine serum is frequently used as a source of hormone factors, essential nutrients, and growth factors needed for a stable growth environment [111]. However, growth with serum has been demonstrated to lead to cellular differentiation and genetic changes, causing the cells to stop mimicking their original clinical phenotype and increase their drug sensitivity $[112,113]$.

Since NB is an orphan disease, a limited number of patient-derived tumor specimens are available. Patientderived xenografts (PDX) are typically taken directly from patients and passaged by subcutaneous or orthotopic implantation of primary tumor pieces or injecting tumor cells into mice. A list of current PDX tumor cells and suppliers can be found in Table 3. Passaging the tumor as a xenograft eliminates in vitro adaptations often observed with sub-cultured cell lines [114, 115]. Braekeveldt et al. and Stewart et al. demonstrated that PDX tumor cells orthotopically grown shared molecular characteristics with primary NB cells, retained classic NB markers, and spontaneously metastasized in murine models $[114,115]$. Increased infiltration and distant metastasis were observed with orthotopically injected PDX cells as compared to orthotopically injected cell lines. In addition, hallmarks of the microenvironment such as vascular infiltration, CAFs, and tumor-associated macrophages (TAMs) with an M2 phenotype were observed in orthotopic PDX tumors [116]. Continuous xenograft transplantation has also been used to identify genetic changes that tumors undergo during metastasis [117]. Regarding patient-derived tumor cells propagated in vitro, generating non-adherent cell lines by culturing with basic fibroblast growth factor, epidermal growth factor, and B27 without serum more closely mimics primary cell lines both in vitro and in vivo [118].

PDX models have been used to evaluate standard of care chemotherapeutics and targeted therapeutics [115]. While PDX tumors are the gold standard for xenograft models, there are still many limitations. The time to establish tumors is long and generating enough consistently sized tumors for large scale therapeutic studies is difficult. In addition, PDX cells are injected into immunocompromised mice, limiting their effectiveness for testing of immunotherapies [119]. In vivo, PDX cells rely on the mouse microenvironment, which does not completely mimic that of a human and confounds potential stromal interactions [116].

\section{Xenografted tumors in "humanized" mice}

A major limitation of xenograft models is the use of immunocompromised mice that lack a fully functional immune system. As more immunotherapies are being developed, identification of preclinical models for testing them is critical. Recently, immunodeficient mice with humanized immune systems have emerged as a method to examine xenografted tumor growth with an engrafted human immune system. These humanized mice (HM) are developed to investigate the interactions between tumor cells and immune cells. There are several methods of developing HM, the most basic of which consists of direct injection of human peripheral blood into immunocompromised mice [116]. Alternatively, stromal tissue can be injected alongside tumor tissue, resulting in an active immune population [120]. More commonly, human hematopoietic stem cells and/or precursor cells (CD34+ or CD133+) are injected into the bone marrow of irradiated immunocompromised mice, allowing for the generation of immune cells including $\mathrm{T}$ cells, B cells, and macrophages [121]. This method is advantageous as a patient's own marrow or blood could be injected into the mouse, allowing for matching between the immune system and tumor. However, successful use of this method has not been reported yet for NB. While the method of hematopoietic stem cell injection is extremely promising, there are still many components that need to be developed. These models still retain mouse stroma and cytokines, which has the potential to prevent complete immune cell differentiation including $\mathrm{T}$ cells and B cells [121]. Furthermore, these models have been shown to exhibit antigen-specific immune responses [122, 123]. The development of accurate humanized mice represents the future for effective pre-clinical therapeutic development. 
Table 3 Available NB PDX Cell Lines and Sources

\begin{tabular}{|c|c|c|c|c|c|}
\hline PDX Line & Stage of Tumor & Age of Patient (Yr.M) & MCYN Status & p53 Status & Organization \\
\hline NB-SD & 4 & 1 & Amp & Mut & Pediatric Preclinical Testing Program \\
\hline NB-1771 & 4 & 2.1 & Amp & Mut & \\
\hline NB-1691 & 4 & 1.9 & Amp & WT & \\
\hline NB-EBC1 & 4 & 2.6 & Non Amp & WT & \\
\hline CHLA-79 & 4 & 2 & Non Amp & WT & \\
\hline NB-1643 & 4 & 1.7 & Amp & WT & \\
\hline NB-1382 & 3 & 3.5 & Amp & N/A & \\
\hline IGR-NB8 & 3 & 5.0 & Amp & N/A & Insitut Curie \\
\hline IGR-N835 & 4 & 2.0 & Amp & N/A & \\
\hline MAP-IC-A23-NB-1 & L2 & 2.6 & Non Amp & $\mathrm{N} / \mathrm{A}$ & \\
\hline MAP-GR-B25-NB-1 & 4 & 4.0 & Amp & N/A & \\
\hline MAP-GR-A99-NB-1 & 4 & 1.10 & Amp & N/A & \\
\hline HSJD-NB-011 & 4 & 2.6 & Amp & N/A & \\
\hline SJNBL012407_X1 & 4 & 0.1 & Amp & N/A & Children's Solid Tumor Network \\
\hline SJNBL013761_X1 & 4 & 3.0 & Non Amp & N/A & \\
\hline SJNBL013762_X1 & 4 & 1.3 & Amp & N/A & \\
\hline SJNBL013763_X1 & $2 B$ & 2.0 & Amp & $\mathrm{N} / \mathrm{A}$ & \\
\hline SJNBL015724_X1 & 4 & 2.0 & Non Amp & N/A & \\
\hline SJNBL046_X & 4 & 2.0 & Amp & N/A & \\
\hline SJNBL108_X & 4 & 3.0 & Non Amp & N/A & \\
\hline SJNBL046145_X1 & 4 & 2.0 & Non Amp & N/A & \\
\hline SJNBL046148_X1 & 4 & 1.11 & Amp & N/A & \\
\hline SJNBL047443_X1 & 4 & 12.0 & Non Amp & N/A & \\
\hline PDX-1 & 4 & 1.4 & Amp & $\mathrm{N} / \mathrm{A}$ & Lund University \\
\hline PDX-2 & 4 & 2.2 & Amp & N/A & \\
\hline PDX-3 & 3 & 2.9 & Amp & N/A & \\
\hline PDX-4 & 4 & 4.9 & Amp & N/A & \\
\hline PDX-5 & 4 & 2.4 & Non Amp & N/A & \\
\hline PDX-6 & $2 B$ & 12.0 & Amp & N/A & \\
\hline COG-N-415x & Unknown & Unknown & Amp & WT & Children's Oncology Group \\
\hline COG-N-440x & Unknown & Unknown & Amp & WT & \\
\hline COG-N-453x & Unknown & Unknown & Amp & WT & \\
\hline COG-N-471x & Unknown & Unknown & Amp & WT & \\
\hline COG-N-496x & Unknown & Unknown & Amp & N/A & \\
\hline COG-N-519x & Unknown & Unknown & Amp & N/A & \\
\hline COG-N-534 m & Unknown & Unknown & Non Amp & N/A & \\
\hline COG-N-549x & Unknown & Unknown & Non Amp & N/A & \\
\hline COG-N-557x & Unknown & Unknown & Amp & N/A & \\
\hline COG-N-573x & Unknown & Unknown & Amp & N/A & \\
\hline Felix (COG-N-426) & Unknown & Unknown & Non Amp & N/A & \\
\hline CHLA-90 & 4 & 8 & Non Amp & N/A & \\
\hline CHLA-136 & 4 & 3 & Amp & N/A & \\
\hline
\end{tabular}

Amp Amplified, Mut Mutation, WT Wild-type, N/A Not Available 


\section{Preclinical in vitro models}

While murine-based systems are the primary method for preclinical testing, advances in tissue culture techniques and in vitro systems are promising for creating accurate NB models. Furthermore, the high cost of murine models as well as cross species pathways and microenvironment differences makes accurate, highthroughput screening challenging. In vitro models encompass a wide range of systems, including traditional adherent monolayer cells, cells grown in 3D suspension cultures (spheroids), and more complex tissue engineering approaches. In addition, they allow for testing of cell response or cell-cell communication in a more controlled manner (e.g. control of cell confluence, ratio of different cell types). While in vitro systems are already used for screening of therapeutics prior to in vivo studies, advances in tissue engineering approaches are creating more accurate models that may better predict clinical efficacy.

\section{Monolayer in vitro systems}

Traditional in vitro models consist of commercially available or lab-derived cell lines adherent to polystyrene dishes, typically grown in the presence of fetal bovine serum, nutrients, and antibiotics. Monolayer culturing is the most common method of evaluating therapeutic efficacy, primarily due to the higher number of cells that can be generated, which allows for rapid screening of many compounds. In addition, these cells can be modified at the genetic level to evaluate the impact of pathway changes on therapeutic efficacy. Methods of inducing gene changes, including transfection, transduction, and more recently using CRISPR systems, have been previously reviewed [124-126]. Genes that have been identified as potential mediators in NB pathways can then be evaluated through knockdown, overexpression, or direct targeting using pathway inhibitors.

MYCN-amplified cell lines have been useful in identifying many proteins and genes that either contribute to or are associated with MYCN. Park et al. determined that high expression of protein arginine methyltransferase 5 (PRMT5) was strongly associated with MYCN amplification. Use of short-interfering RNA to reduce expression of PRMT5 decreased MYCN expression and caused cell death in MYCN-amplified cell lines [127]. Ambrosio et al. identified lysine-specific demethylase 1 (LSD1), a histone modifier, as a transcriptional modulator of NDRG1 (N-Myc Downstream-Regulated Gene 1, a metastasis suppressor). In both in vitro models and patient samples, high levels of LSD1 correlated with low levels of NDRG1 [128].

RNAi and CRISPR screens have been useful in identifying genes that could be targets for therapeutic regimes. In a kinome-wide RNAi screen, Shen et al. targeted protein kinases and kinase associated genes to identify sensitizing and inhibitory kinases to HDAC8 inhibitors. Knockdown of ALK sensitized NB cells to HDAC8 inhibitors. This was further confirmed through combinatorial treatment of NB tumors with crizotinib, an ALK inhibitor, and HDAC8 inhibitors resulting in increased cell death [129]. CRISPR-Cas9 screening of MYCNamplified NB cells by Chen et al. demonstrated cellular dependency on the PRCR2 complex, specifically EZH2. MYCN binds at the EZH2 promoter, repressing neuronal differential of NB cells, which promotes a more tumorigenic phenotype. This was further confirmed through genetic and pharmacological suppression of EZH2, which inhibited NB growth. These screens are useful in identifying key pathways that could be therapeutically targeted in NB [130].

In addition to screening through genetic modifications, screens of high numbers of cell lines and therapies can be conducted in vitro. Mahoney et al. screened 482 cell lines with metabolic inhibitors [131]. Neuroendocrine cells, specifically NB cells, showed a higher sensitivity to NB-598, an inhibitor of enzyme squalene epoxidase (SQLE). This suggests that targeting this pathway may have therapeutic potential. Similarly, Michaelis et al. screened 321 cancer cell lines (from 26 different types of cancer) for response to flubendazole (inhibitor of microtubule function) [132]. NB was identified as highly sensitive to flubendazole, reducing viability of $140 \mathrm{NB}$ cell lines. Large scale screens have the potential to identify novel therapeutics for NB.

\section{Monolayer co-culture models}

The NB tumor microenvironment is composed of multiple cell types including vascular cells, tumor-associated macrophages, fibroblasts, T-cells, natural killer (NK) cells, and others [133]. Each cell type has the potential to influence NB phenotype based on cell-cell interactions, paracrine signaling and secreted factors. Hashimoto et al. co-cultured NB cells with two prominent microenvironment cells, fibroblasts and macrophages. Consistent with clinical results that correlated areas of fibroblasts with aggressive NB phenotype, co-culturing with fibroblasts increased NB cell proliferation [133]. In addition, peripheral blood macrophages were cocultured with NB cells directly and indirectly using the NB cell-conditioned medium NB cell-conditioned medium transitioned the macrophages into a pro-tumor survival M2 phenotype, or TAM phenotype, suggesting a crosstalk between NB cells and macrophages supporting tumor progression. Indirect co-culture of NB cells in macrophage medium increased tumor invasiveness (through a Matrigel based invasion assay) likely through CXCL2 secretion [133]. Direct co-culture of NB cells and macrophages did not result in an increase in NB 
proliferation; however, it did enhance the invasiveness of NB cells. In co-culture with NB cells, both macrophage and fibroblasts exhibited enhanced invasion.

Borriello et al. co-cultured NB cells with fibroblasts derived from MSC cells. They observed that fibroblasts induced a pro-tumorigenic effect on NB cells, including increased proliferation and inhibited apoptosis [110]. Chemoresistance to etoposide and melphalan was evaluated using chemosensitive and chemoresistant NB cell lines co-cultured with fibroblasts. It was determined that co-culturing significantly reduced responsiveness of both the NB cell lines and the fibroblasts to chemotherapy. This suggests that presence of fibroblasts in the tumor bed may contribute to chemoresistance. The authors also determined that these effects do not require cell-tocell contact but are likely due to soluble factors, many of which have convergent activity in the STAT3 and ERK $1 / 2$ signaling pathways [110].

To evaluate the effect of ECM components on selforganization in co-cultures, Rizvanov et al. co-cultured NB cells MSCs on different surfaces including poly-llysine, fibronectin, gelatin, collagen I, and Matrigel to examine the surface effect on cell phenotype [134]. No phenotypic differences were observed between noncoated surfaces and surfaces coated with poly-l-lysine, fibronectin, gelatin, or collagen I. In these culture conditions, cells organized into distinct patterns with channels of MSCs and islands of NB cells, comparable to a tumor. However, when cultured on Matrigel, MSCs organized themselves into a dense core with a surrounding ring of NB cells. The authors suggested that this phenotype was more representative of metastatic tumors and could be used as a potential model for metastasis. In addition, exposure of this co-culture model to oxidative stress through the addition of hydrogen peroxide demonstrated that the presence of MSCs increased NB cell viability [134]. As oxidative stress is one of the primary death mechanisms of radiation therapy, this finding implies that this culture system is more mimetic of an in vivo resistant tumor [134].

Co-culturing of NB and NK cells is frequently used as part of an antibody-dependent cell-mediated cytotoxicity assay for testing of immunotherapies. The NK cells induce lysis of NB cells in the presence of antibodies [135]. Similar studies have been carried out to test therapeutic efficacy with leukocytes, peripheral blood mononuclear cells, and granulocytes [136, 137]. These systems have been used to test out combination therapies of cytokines or retinoids with immunotherapies [138, 139]. However, there has been little work done with longerterm culture of these immune cell populations and characterization of the impact of co-culture on tumor cells and immune cells. As immune cells are present in NB tumors, further development of these co-culture models may be critical to developing better therapeutic strategies.

NB cells have also been cultured with hepatocytes, as NB frequently metastasizes to the liver [140, 141]. The authors observed resistance to apoptosis by the NB cells, induction of apoptosis in the hepatocytes, and an increase in VEGF secretion. The hepatocytes induced overexpress of Bcl-2 by the NB cells, thereby reducing $\mathrm{NB}$ apoptosis and establishing $\mathrm{Bcl}-2$ as a therapeutic target for NB liver metastasis. Interestingly, studies focusing on VEGF secretion demonstrated that expression of VEGF receptors is highly heterogeneous across NB lines, which likely extends to patient tumors [140]. It is therefore critical to examine the expression of each individual tumor when investigating the use of anti-VEGF therapies $[140,141]$.

Co-culture systems also enable the investigation of cell migration in the presence of other cell types, as commonly evaluated using transwell plates. NB cells in transwell systems have been used to examine the impact of $\mathrm{NB}$ cell MYCN-amplification level on migration of human umbilical vein endothelial cells (HUVECs). HUVEC migration was proportionate to MYCNamplification level. In addition, it was demonstrated that the efficacy of a PI3K inhibitor NVP-BEZ235 (as angiogenesis is regulated by PI3K) was dependent on MYCN. This suggests a link between angiogenesis, the PI3K pathway, and MYCN in NB [142]. Additional studies have demonstrated that growth of HUVEC in medium conditioned by NB cells induced vessel angiogenesis and upregulation of VEGF and IL-8 [143].

Co-culturing NB cells with other cell types present within the tumor microenvironment such as fibroblasts, immune cells, and cells present at metastatic sites allows for understanding of the impact of tumor microenvironment on NB phenotype [133]. These culture systems allow for an increase in understanding of tumor heterogeneity as well as critical tumor signaling pathways. For preclinical therapeutic testing, co-culture systems provide an opportunity to better understand tumor escape as mediated by signaling factors secreted from neighboring cells and how therapies influence non-tumor cells. Incorporating additional microenvironment stress components, including hypoxia and mechanics, would add additional complexity and relevance for drug development.

\section{$3 D$ in vitro models: spheroid}

Growth of NB cells in spheroids has been used as a preclinical model, as spheroids have been suggested to more accurately mimic the clinical phenotype as a drug screening model $[114,116,118]$. NB spheroid cultures can be generated using low or non-attachment culture dishes, coated plates or dishes, or the removal of serum 
from the medium [144-147]. Compared to cells grown in monolayer culture, spheroid cultures exhibited increased expression of metabolic markers, cell stress response proteins, cell structure proteins, and transport polypeptides [148]. Sidarovich et al. used spheroids for high throughput drug screening of over 300 FDAapproved anti-cancer compounds or compounds undergoing clinical trials [149]. From this screen, the authors identified, and later evaluate in vivo, two compounds, ponatinib and axitinib, as potential new therapies for NB based on toxicity, molecular target, and side effects [149].

Spheroids are advantageous as once they reached a critical size of $>100 \mu \mathrm{m}$, they begin to exhibit microenvironment changes due to nutrient and oxygen gradients [146]. Changes in nutrient and oxygen gradients induce therapeutic resistance through upregulation of pro-survival and tumor promoting pathways [146]. Growth of NB cell lines and patient-derived tumor cells as non-adherent spheroids demonstrated retention of cellular phenotype more closely resembling primary tumors [118]. Additional advantages of spheroids include altered diffusion and ECM deposition that has the potential to impact therapeutic efficacy [144].

Culturing as spheroids demonstrated selectively for tumor-initiating cells [150]. Coulon et al. evaluated spheroid formation of serially passaged PDXs and found that only the bone marrow-derived metastatic cells (the patient equivalent of stage 4) were able to generate spheroids. The generation of spheroids suggests that the metastatic cells have a high degree of self-renewal and are likely enriched with a cancer stem cell population [151]. This finding is important as it supports the use of spheroids for testing drugs that are associated with tumor stem cells such as Notch and WNT [152, 153]. MYCN-amplified tumor cells exhibit a higher propensity for spheroid formation than non-MYCN-amplified cells [151]. The ability to form spheroids is directly dependent on the cellular differentiation status, or stemness. Treatment with 13-cis-retinoic acid, a differentiation agent that induces a neuronal phenotype, inhibited spheroid formation [154].

Gransbury et al. fabricated spheroids of different diameters (ranging from 50 to $800 \mu \mathrm{m}$ ) to evaluate different microenvironments [146]. Using the spheroid culture, the authors were able to examine different levels of hypoxia, diffusion, and redox state, giving them further insights into the therapeutic potential than otherwise possible with 2D culture models [146]. Two different cancer therapies were identified: NAMI-A and KP1019 which are $\mathrm{Ru}^{\mathrm{III}}$-based anti-metastatic and cytotoxic drugs that are administered in a non-active form and subsequently become activated under oxidative environments. Cuperus et al. used spheroid cultures to study fenretinide, which has been shown to induce apoptosis through retinoic acid and reactive oxygen species dependent pathways [155]. In combination with buthionine sulfoximine, an inhibitor of glutathione synthesis, fenretinide reduced proliferation and induced apoptosis both in monolayer and in spheroids.

Spheroid culture systems have been used to model drug diffusion challenges and develop drug delivery systems with improved tumor penetration. Sagnella et al. used spheroid culture of NB to evaluate the therapeutic potential of $\mathrm{EDV}^{\mathrm{m}}$ nanocells - a bacterially-derived drug delivery system consisting of nonviable cells that are $400 \mathrm{~nm}$ in diameter. The authors demonstrated that the EGFR-targeted nanocells enhanced penetrance of doxorubicin compared to non-targeted doxorubicin loaded nanocells and doxorubicin without a delivery vehicle, resulting in increased apoptosis. These findings were confirmed in an orthotopic xenograft model [156].

Spheroids have been directly compared to monolayer cells to determine efficacy of different forms of radiotherapy [157]. Cunningham et al. demonstrated that the Auger electron-emitting conjugates ${ }^{123}$ I-meta-iodobenzylguanidine and ${ }^{125} \mathrm{I}$ - meta-iodobenzylguanidine and the alpha-emitting conjugate ${ }^{211}$ At- astatobenzylguanidine were highly toxic to cells grown in monolayer and in small spheroids. In larger spheroids, the Auger electron emitters were relatively ineffective. However, a beta-emitting conjugate ${ }^{131} \mathrm{I}$-astatobenzylguanidine was highly effective in large spheroids. This work highlighted how spheroids may assist in identifying therapies that may be more successful clinically, either for killing macroscopic tumors [157]. Spheroids have also been used to evaluate specific pathway inhibitors such as multikinase inhibitors and oxidative phosphorylation inhibitors $[158,159]$.

Spheroid cultures are an important part of preclinical testing. They are currently the most widely used approach to bridge the gap between two-dimensional cell culture and the in vivo tumor microenvironment [147]. Growth in spheroids exhibits phenotypes better resembling in vivo tumors [119]. In addition to a higher degree of mimicry to in vivo tumors, spheroids are advantageous as they allow for rapid preclinical testing [147]. They also exhibit cell-cell contact similar to that of an in vivo tumor and exhibit similar diffusion limitations for nutrients and therapeutics [114, 116, 118]. Limitations to spheroid tumors include heterogeneity in sizes, a necrotic core in large spheroids, and lack of additional environmental components such the stroma and immune cells [160, 161]. Non-uniform spheroid generation results in varying diffusion gradients, making properly controlled experiments challenging. Frequently tumors in vivo exhibit a hypoxic core, with the necrotic cells secreting factors which induce angiogenesis, thus 
preventing the tumors from becoming overly necrotic. Angiogenesis does not occur without a vascular component in the spheroid cultures, so care must be taken to avoid large regions of necrosis. Stroma and immune cells are critical components of the tumor microenvironment and can impact oncogenic pathways and therapeutic efficacy. Co-culture with stroma and immune components in spheroids has been demonstrated to be effective for other cancer types, and presents a unique opportunity to mimic NB the tumor microenvironment [162-165].

\section{Hydrogels and scaffolds for 3D tumor growth}

Limited work has been done with NB growth in 3D outside of spheroid cultures. However, 3D growth of NB cells can be achieved using a broad range of scaffold and or hydrogel materials. ECM hydrogels such as collagen I and Matrigel have been used to mimic tumor ECM and provide a backbone for 3D tumor growth. These 3D matrices have the potential to impact gene expression and cell morphology [166]. Li et al. used microarray analysis to demonstrate differences in gene expression in cells grown in monolayer, collagen I hydrogels, and Matrigel hydrogels [166]. All 3D culture conditions induced morphological differences as compared to monolayer. Cells grown in collagen I exhibited longer neurites than those grown in Matrigel, likely due to the fibrils present in the collagen. This study focused on genes associated with morphology and neurite outgrowth; studies evaluating the impact on key NB tumor pathways have not been performed.

Mitchell et al., used spheroids embedded in collagen hydrogels to evaluate the invasive behavior of NB [167]. Mixed cell population of NB cells, neuronal type NB cells and stromal type NB cells, exhibited a heterogeneous invasive population. Crosstalk between both cell types was identified where neuronal type NB cells decreased invasion of stromal type NB cells and stromal type NB cells enhanced invasion in neuronal types NB cells [167]. This could be useful in identifying which cell populations to target therapeutically to decrease metastasis.

Studies have suggested the presence of ECM molecules as well as growth in 3D can impact the responsiveness to therapeutics [168]. Mitchell et al., evaluated siRNA-targeting Rac on both single cell suspensions and cells suspended in 3D collagen hydrogels. Cell lines with different morphologies, stromal, neuronal, or combination, were evaluated. As Rac inhibition is most effective in cells with elongated, invasive morphology, studies in 3D were critical to identifying differences in invasion and morphology for determining therapeutic efficacy [168].

Non-hydrogel-based scaffolds typically consist of porous or fibrous materials (either synthetic or biological- derived) that may mimic structures present in vivo. They are advantageous as they have tunable degradation based on material properties or material choice, can be functionalized to mimic the native environment, and provide control over spatial organization. Scaffolded approaches have been used to model other cancer types, but limited scaffolded approaches have been utilized for NB. Curtin et al. used lyophilized collagen I/glycosaminoglycan and collagen I/nanohydroxyapatite scaffolds for culturing of KELLY NB cells and a cisplatin-resistant KELLY cell derivative [169]. The NB cells exhibited reduced growth in $3 \mathrm{D}$ as compared to monolayer culturing, which is consistent with previously demonstrated results in other cancer cell lines $[170,171]$. The cisplatin-resistant cell line exhibited increased proliferation in the collagen/hydroxyapatite scaffold as compared to the collagen/glycosaminoglycan scaffold. Response to cisplatin was evaluated in monolayer, 3D culture, and an in an orthotopic xenograft model. Both 3D culture models exhibited similar chemosensitivity to the orthotopic in vivo model, with a reduced response observed as compared to the monolayer culture. Using these scaffolds, KELLY NB cells grown in 2D and 3D were used for evaluation of liposomes delivering miRNA for therapeutic gene silencing [169]. Unlike the chemotherapy studies, miRNA exhibited similar effects in 2D and 3D highlighting the potential usefulness of miRNA as a therapeutic.

Scaffold based studies have also been used for biomechanical modeling. One scaffold-based study used graphene-augmented nanofiber scaffolds to determine the impact of an "out-of-comfort" nanobiomechanical environment for NB cells [172]. Growth on highly aligned graphene fibers changed the morphology from flat to a more rounded shape as the cells enveloped the fibers. In addition, increased gene expression of promigratory and pro-invasion markers were observed [172]. This represents a potential system to examine the more migratory or more metastatic NB cells, and develop therapeutics aimed at effectively inhibiting those cells.

3D scaffold-based modeling has been explored for other pediatric blastoma and similar pediatric cancers. For example, polymeric poly (lactide-co-glycolide) nanoparticles have been used to generate 3D cultures of retinoblastoma cells. Etoposide and doxorubicin loaded nanoparticles induced higher cytotoxicity towards 2D cultured cells as compared to 3D cultured cells. The authors correlated this to a decreased drug exposure in 3D cultured cells as compared to 2D, likely due to diffusion barriers [173]. Electrospun poly( $\varepsilon$-caprolactone) microfiber scaffolds have been used to generate models of Ewing sarcoma [174]. Using these models, cells grown in microfiber scaffolds exhibited reduced proliferation as compared to $2 \mathrm{D}$ cultured cells. Cell growth on the 
microfiber scaffold was comparable to xenograft growth, as were levels of relevant pathways such as IGF-1R signaling and mTor [174]. Ewing sarcoma cell lines and PDX cells have been grown on a porous matrix composed of freeze-dried type I collagen and hyaluronic acid meant to mimic both mechanical and biological cues present in the body. Both the Ewing sarcoma cell lines and PDX cells demonstrated increased drug resistance and closer resemblance of in vivo tumors [175]. Scaffold-based approaches could be applied to preclinical NB modeling. These approaches are advantageous as scaffolds can be fabricated from materials that mimic the native tumor ECM (both chemically and mechanically). In addition, use of layered scaffold models with multiple cell types can be used to model different components of the tumor architecture.

\section{D co-culture models}

3D models can be expanded to include multiple cell types found in the tumor microenvironment. Villasante et al. used a tissue engineered model consisting of sheets of HUVEC cells and NB cells stacked to reach a total height of $\sim 100 \mu \mathrm{m}$ placed on a "vascular bed" made of collagen, fibrin, and HUVEC cells. The stacked vascular bed was placed on a collagen gel with microchannels to mimic vessel-like structures within NB [176]. This system was cultured in a perfusion bioreactor to mimic the in vivo environment. The therapeutic potential of isotretinoin was evaluated using this model. Isotretinoin blocks cell proliferation and reduces tumor vasculature in vivo. Isotretinoin increased cellular apoptosis, and decreased mRNA levels of NB markers MYCN and GLI1. In addition, isotretinoin weakened and disassembled the vascular networks by blocking cell-to-cell adhesions. Populations of both cancer cells and vascular cells resistant to isotretinoin were identified. Further characterization of resistant cells identified an increase in SOX2 expression in the resistant population. This correlation had not previously been identified using conventional 2D culture [176].

NB cells and MSCs have been co-encapsulated inside collagen I microspheres to investigate the impact of the stromal environment on NB growth [177]. The MSCs were used as they exhibit a fibroblast like morphology, resembling CAFs in vivo. The MSCs induced increased NB proliferation, suggesting that the stromal component has a direct impact on tumor growth. The cultured NB cells and MSCs exhibited a rosette-like phenotype, resembling that of clinical NB. MMP9-expressing cells were found primarily on the periphery of the microspheres, which is the more migratory region. Previous work with these microspheres identified a hypoxic core, which could be evaluated with the NB model to mimic the hypoxic core frequently found in clinical NB tumors [178].

Multicellular models grown in 3D are an emerging trend in tissue engineering in an attempt to understand the complex tumor microenvironment. These models remain largely unexplored for NB; however, preliminary studies suggest that they can provide insightful information about tumor pathway crosstalk and potential therapeutic efficacy. The heterogeneity in NB, both within the tumor microenvironment and across individual tumors, represents a challenge to effective therapeutic development. In vitro 3D culture of $\mathrm{NB}$ cells with relevant microenvironment cells would allow for elucidation of critical pathways and mechanisms of resistance that exist in vivo.

\section{Conclusion}

Neuroblastoma is a heterogeneous disease, both in clinical presentation and prognosis. Understanding of critical pathways in disease progression and development of effective preclinical therapies for NB remains a challenge. Murine models, including GEMM, syngeneic, and xenograft have been developed for therapeutic testing, particularly geared towards mimicking high-risk phenotypes. However, challenges remain as therapeutic development trends toward immunotherapies and a mouse capable of combining a human NB tumor with an intact immune system has not been created. The future of this likely lies within humanized immune mouse models. These have the potential to use a mouse as a vehicle to evaluate a human tumor, with an intact human immune system.

Tissue engineering provides a promising approach for development of systems capable of high throughput therapeutic evaluation using multicellular systems. The growth of cells in 3D allows for diffusion gradients of nutrients, oxygen, and therapeutics similar to those found in vivo. For development of effective models, it is critical to incorporate multiple cell types (stromal, vascular, and immune) in an environment capable of mimicking relevant diffusion limitations. Patient derived tumors are the most representative of the heterogeneous tumor phenotype. In the future, combining patient tumors with patient-derived stroma and immune cells may achieve a more accurate model for preclinical therapeutic testing.

\footnotetext{
Abbreviations

ALK: Anaplastic lymphoma kinase; CAF: Cancer associated fibroblast;

ECM: Extracellular matrix; GEMM: Genetically engineered mouse model;

HM: Humanized mice; MSCs: Mesenchymal stem cells; NB: Neuroblastoma;

NK: Natural killer; PDX: Patient-derived xenografts; SV40 Tag: Simian virus 40

T-antigen; TAM: Tumor associate macrophage
}

Acknowledgements

Not Applicable. 


\section{Authors' contributions}

$\mathrm{KO}$ wrote and edited the manuscript. JM conceptualized, edited, and reviewed the manuscript. All authors read and approved the final manuscript.

\section{Funding}

Not Applicable.

\section{Availability of data and materials}

Data sharing not applicable to this article as no datasets were generated or analyzed during the current study.

\section{Ethics approval and consent to participate} Not Applicable.

\section{Consent for publication}

Not Applicable.

\section{Competing interests}

The authors declare that they have no competing interests.

\section{Received: 9 April 2019 Accepted: 19 November 2019} Published online: 20 December 2019

\section{References}

1. Brodeur GM, Nakagawara A. Molecular basis of clinical heterogeneity in neuroblastoma. Am J Pediatr Hematol Oncol. 1992:14(2):111-6.

2. Ries LAGSM, Gurney JG, Linet M, Tamra T, Young JL, Bunin GR. Cancer incidence and survival among children and adolescents: United States SEER Program 1975-1995. National Cancer Institute, SEER Program. Bethesda: NIH Pub; 1999. p. 99-4649.

3. Stiller CA, Parkin DM. International variations in the incidence of neuroblastoma. Int J Cancer. 1992;52(4):538-43.

4. Matthay KK, Villablanca JG, Seeger RC, Stram DO, Harris RE, Ramsay NK, Swift P, Shimada H, Black CT, Brodeur GM, et al. Treatment of high-risk neuroblastoma with intensive chemotherapy, radiotherapy, autologous bone marrow transplantation, and 13-cis-retinoic acid. Children's Cancer Group. N Engl J Med. 1999;341(16):1165-73. https://doi.org/10.1056/ NEJM199910143411601.

5. DuBois SG, Kalika Y, Lukens JN, Brodeur GM, Seeger RC, Atkinson JB, Haase GM, Black CT, Perez C, Shimada H, et al. Metastatic sites in stage IV and IVS neuroblastoma correlate with age, tumor biology, and survival. J Pediatr Hematol Oncol. 1999:21(3):181-9.

6. Morgenstern DA, London WB, Stephens D, Volchenboum SL, Simon T, Nakagawara A, Shimada H, Schleiermacher G, Matthay KK, Cohn SL, et al. Prognostic significance of pattern and burden of metastatic disease in patients with stage 4 neuroblastoma: A study from the International Neuroblastoma Risk Group database. Eur J Cancer. 2016;65:1-10. https://doi. org/10.1016/j.ejca.2016.06.005.

7. Shojaei-Brosseau T, Chompret A, Abel A, de Vathaire F, Raquin MA, Brugieres L, Feunteun J, Hartmann O, Bonaiti-Pellie C. Genetic epidemiology of neuroblastoma: a study of 426 cases at the Institut Gustave-Roussy in France. Pediatr Blood Cancer. 2004;42(1):99-105. https://doi.org/10.1002/pbc 10381.

8. Seeger RC, Brodeur GM, Sather H, Dalton A, Siegel SE, Wong KY, Hammond D. Association of multiple copies of the $\mathrm{N}$-myc oncogene with rapid progression of neuroblastomas. N Engl J Med. 1985;313(18):1111-6. https:// doi.org/10.1056/NEJM198510313131802

9. Brodeur GM, Seeger RC, Schwab M, Varmus HE, Bishop JM. Amplification of $\mathrm{N}$-myc in untreated human neuroblastomas correlates with advanced disease stage. Science. 1984;224(4653):1121-4.

10. Martinsson T, Sjoberg RM, Hedborg F, Kogner P. Deletion of chromosome $1 \mathrm{p}$ loci and microsatellite instability in neuroblastomas analyzed with shorttandem repeat polymorphisms. Cancer Res. 1995;55(23):5681-6.

11. White PS, Thompson PM, Gotoh T, Okawa ER, Igarashi J, Kok M, Winter C, Gregory SG, Hogarty MD, Maris JM, et al. Definition and characterization of a region of 1 p36.3 consistently deleted in neuroblastoma. Oncogene. 2005; 24(16):2684-94. https://doi.org/10.1038/sj.onc.1208306.

12. White PS, Thompson PM, Seifried BA, Sulman EP, Jensen SJ, Guo C, Maris JM, Hogarty MD, Allen C, Biegel JA, et al. Detailed molecular analysis of
1 p36 in neuroblastoma. Med Pediatr Oncol. 2001;36(1):37-41 doi:10.1002/ 1096-911X(20010101)36:1 < 37::AID-MPO1010 > 3.0.CO:2-L.

13. Plantaz D, Vandesompele J, Van Roy N, Lastowska M, Bown N, Combaret V, Favrot MC, Delattre O, Michon J, Benard J, et al. Comparative genomic hybridization $(\mathrm{CGH})$ analysis of stage 4 neuroblastoma reveals high frequency of 11 q deletion in tumors lacking MYCN amplification. Int J Cancer. 2001;91(5):680-6

14. Spitz R, Hero B, Ernestus K, Berthold F. Deletions in chromosome arms 3p and $11 \mathrm{q}$ are new prognostic markers in localized and $4 \mathrm{~s}$ neuroblastoma. Clin Cancer Res. 2003;9(1):52-8.

15. Perez CA, Matthay KK, Atkinson JB, Seeger RC, Shimada H, Haase GM, Stram DO, Gerbing RB, Lukens JN. Biologic variables in the outcome of stages I and II neuroblastoma treated with surgery as primary therapy: a children's cancer group study. J Clin Oncol. 2000;18(1):18-26. https://doi.org/10.1200/ JCO.2000.18.1.18.

16. Strother DR, London WB, Schmidt ML, Brodeur GM, Shimada H, Thorner P, Collins $\mathrm{MH}$, Tagge $\mathrm{E}$, Adkins $\mathrm{S}$, Reynolds $\mathrm{CP}$, et al. Outcome after surgery alone or with restricted use of chemotherapy for patients with low-risk neuroblastoma: Results of Children's Oncology Group Study P9641. J Clin Oncol. 2012;30(15):1842-8

17. Kushner BH, Cheung NK, LaQuaglia MP, Ambros PF, Ambros IM, Bonilla MA, Gerald WL, Ladanyi M, Gilbert F, Rosenfield NS, et al. Survival from locally invasive or widespread neuroblastoma without cytotoxic therapy. J Clin Oncol. 1996;14(2):373-81. https://doi.org/10.1200/JCO.1996.14.2.373.

18. Pearson AD, Pinkerton CR, Lewis IJ, Imeson J, Ellershaw C, Machin D European Neuroblastoma Study G, Children's C, Leukaemia G. High-dose rapid and standard induction chemotherapy for patients aged over 1 year with stage 4 neuroblastoma: a randomised trial. Lancet Oncol. 2008;9(3): 247-56. https://doi.org/10.1016/S1470-2045(08)70069-X.

19. Cheung NK, Kushner BH, LaQuaglia M, Kramer K, Gollamudi S, Heller G, Gerald W, Yeh S, Finn R, Larson SM, et al. N7: a novel multi-modality therapy of high risk neuroblastoma (NB) in children diagnosed over 1 year of age. Med Pediatr Oncol. 2001;36(1):227-30 doi:10.1002/1096-911X(20010101)36: $1<227:$ AID-MPO1055 > 3.0.CO;2-U.

20. Berthold F, Boos J, Burdach S, Erttmann R, Henze G, Hermann J, Klingebiel T, Kremens B, Schilling FH, Schrappe $M$, et al. Myeloablative megatherapy with autologous stem-cell rescue versus oral maintenance chemotherapy as consolidation treatment in patients with high-risk neuroblastoma: a randomised controlled trial. Lancet Oncol. 2005;6(9):649-58. https://doi.org/ 10.1016/S1470-2045(05)70291-6.

21. Langler A, Christaras A, Abshagen K, Krauth K, Hero B, Berthold F. Topotecan in the treatment of refractory neuroblastoma and other malignant tumors in childhood - a phase-II-study. Klin Padiatr. 2002;214(4):153-6. https://doi. org/10.1055/s-2002-33175.

22. Wiseman GA, Kvols LK. Therapy of neuroendocrine tumors with radiolabeled MIBG and somatostatin analogues. Semin Nucl Med. 1995;25(3):272-8.

23. Wassberg E, Pahlman S, Westlin JE, Christofferson R. The angiogenesis inhibitor TNP-470 reduces the growth rate of human neuroblastoma in nude rats. Pediatr Res. 1997;41(3):327-33. https://doi.org/10.1203/00006450199703000-00004

24. Klement G, Baruchel S, Rak J, Man S, Clark K, Hicklin DJ, Bohlen P, Kerbel RS. Continuous low-dose therapy with vinblastine and VEGF receptor-2 antibody induces sustained tumor regression without overt toxicity. J Clin Invest. 2000;105(8):R15-24. https://doi.org/10.1172/JCl8829.

25. Evans AE, Kisselbach KD, Liu X, Eggert A, Ikegaki N, Camoratto AM, Dionne C, Brodeur GM. Effect of CEP-751 (KT-6587) on neuroblastoma xenografts expressing TrkB. Med Pediatr Oncol. 2001;36(1):181-4 doi:10.1002/1096911X(20010101)36:1 < 181::AID-MPO1043 > 3.0.CO;2-Q.

26. Ho R, Minturn JE, Hishiki T, Zhao H, Wang Q, Cnaan A, Maris J, Evans AE, Brodeur GM. Proliferation of human neuroblastomas mediated by the epidermal growth factor receptor. Cancer Res. 2005;65(21):9868-75. https:// doi.org/10.1158/0008-5472.CAN-04-2426.

27. Yu AL, Uttenreuther-Fischer MM, Huang CS, Tsui CC, Gillies SD, Reisfeld RA, Kung FH. Phase I trial of a human-mouse chimeric anti-disialoganglioside monoclonal antibody ch14.18 in patients with refractory neuroblastoma and osteosarcoma. J Clin Oncol. 1998;16(6):2169-80. https://doi.org/10.1200/ JCO.1998.16.6.2169.

28. Gonzalez S, Naranjo A, Serrano LM, Chang WC, Wright CL, Jensen MC. Genetic engineering of cytolytic T lymphocytes for adoptive T-cell therapy of neuroblastoma. J Gene Med. 2004;6(6):704-11. https://doi.org/10.1002/ jgm.489. 
29. Bolesta E, Kowalczyk A, Wierzbicki A, Rotkiewicz P, Bambach B, Tsao CY, Horwacik I, Kolinski A, Rokita H, Brecher M, et al. DNA vaccine expressing the mimotope of GD2 ganglioside induces protective GD2 cross-reactive antibody responses. Cancer Res. 2005;65(8):3410-8. https://doi.org/10.1158/ 0008-5472.CAN-04-2164.

30. Ackermann S, Cartolano M, Hero B, Welte A, Kahlert Y, Roderwieser A, Bartenhagen C, Walter E, Gecht J, Kerschke L, et al. A mechanistic classification of clinical phenotypes in neuroblastoma. Science. 2018 362(6419):1165-70. https://doi.org/10.1126/science.aat6768.

31. Mouse Genome Sequencing C, Waterston RH, Lindblad-Toh K, Birney E, Rogers J, Abril JF, Agarwal P, Agarwala R, Ainscough R, Alexandersson M, et al. Initial sequencing and comparative analysis of the mouse genome. Nature. 2002;420(6915):520-62. https://doi.org/10.1038/nature01262.

32. Walrath JC, Hawes JJ, Van Dyke T, Reilly KM. Genetically engineered mouse models in cancer research. Adv Cancer Res. 2010;106:113-64. https://doi. org/10.1016/S0065-230X(10)06004-5.

33. Branda CS, Dymecki SM. Talking about a revolution: The impact of sitespecific recombinases on genetic analyses in mice. Dev Cell. 2004;6(1):7-28.

34. Weiss WA, Aldape K, Mohapatra G, Feuerstein BG, Bishop JM. Targeted expression of MYCN causes neuroblastoma in transgenic mice. Embo J. 1997;16(11):2985-95. https://doi.org/10.1093/emboj/16.11.2985.

35. Chesler L, Goldenberg DD, Seales IT, Satchi-Fainaro R, Grimmer M, Collins R, Struett C, Nguyen KN, Kim G, Tihan T, et al. Malignant progression and blockade of angiogenesis in a murine transgenic model of neuroblastoma. Cancer Res. 2007;67(19):9435-42. https://doi.org/10.1158/0008-5472.Can-07-1316.

36. Burkhart CA, Watt F, Murray J, Pajic M, Prokvolit A, Xue C, Flemming C, Smith J, Purmal A, Isachenko N, et al. Small-molecule multidrug resistanceassociated protein 1 inhibitor reversan increases the therapeutic index of chemotherapy in mouse models of neuroblastoma. Cancer Res. 2009;69(16): 6573-80. https://doi.org/10.1158/0008-5472.CAN-09-1075.

37. Henssen A, Althoff K, Odersky A, Beckers A, Koche R, Speleman F, Schafers S,

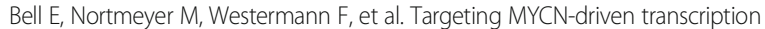
by BET-bromodomain inhibition. Clin Cancer Res. 2016;22(10):2470-81.

38. Chipumuro E, Marco E, Christensen CL, Kwiatkowski N, Zhang T, Hatheway CM, Abraham BJ, Sharma B, Yeung C, Altabef A, et al. CDK7 inhibition suppresses super-enhancer-linked oncogenic transcription in MYCN-driven cancer. Cell. 2014;159(5):1126-39. https://doi.org/10.1016/j.cell.2014.10.024.

39. Colicchia V, Petroni M, Guarguaglini G, Sardina F, Sahun-Roncero M, Carbonari M, Ricci B, Heil C, Capalbo C, Belardinilli F, et al. PARP inhibitors enhance replication stress and cause mitotic catastrophe in MYCNdependent neuroblastoma. Oncogene. 2017;36(33):4682-91. https://doi.org/ 10.1038/onc.2017.40

40. Lu J, Guan S, Zhao Y, Yu Y, Woodfield SE, Zhang H, Yang KL, Bieerkehazhi S, Qi L, Li X, et al. The second-generation ALK inhibitor alectinib effectively induces apoptosis in human neuroblastoma cells and inhibits tumor growth in a TH-MYCN transgenic neuroblastoma mouse model. Cancer Lett. 2017; 400:61-8. https://doi.org/10.1016/j.canlet.2017.04.022.

41. Waldeck K, Cullinane C, Ardley K, Shortt J, Martin B, Tothill RW, Li J, Johnstone RW, McArthur GA, Hicks RJ, et al. Long term, continuous exposure to panobinostat induces terminal differentiation and long term survival in the TH-MYCN neuroblastoma mouse model. Int J Cancer. 2016; 139(1):194-204. https://doi.org/10.1002/ijc.30056.

42. Dolman MEM, Poon E, Ebus ME, den Hartog IJM, van Noesel CJM, Jamin Y, Hallsworth A, Robinson SP, Petrie K, Sparidans RW, et al. Cyclin-dependent kinase inhibitor AT7519 as a potential drug for MYCN-dependent neuroblastoma. Clin Cancer Res. 2015;21(22):5100-9.

43. Chen ZH, Wang ZY, Pang JC, Yu Y, Bieerkehazhi S, Lu JX, Hu T, Zhao YL, Xu $X$, Zhang $H$, et al. Multiple CDK inhibitor dinaciclib suppresses neuroblastoma growth via inhibiting CDK2 and CDK9 activity. Sci Rep Uk. 2016;6:ARTN 29090. https://doi.org/10.1038/srep29090.

44. Mao Y, Eissler N, Blanc KL, Johnsen Jl, Kogner P, Kiessling R. Targeting suppressive myeloid cells potentiates checkpoint inhibitors to control spontaneous neuroblastoma. Clin Cancer Res. 2016;22(15):3849-59.

45. Teitz T, Inoue M, Valentine MB, Zhu KJ, Rehg JE, Zhao W, Finkelstein D, Wang YD, Johnson MD, Calabrese C, et al. Th-MYCN mice with caspase-8 deficiency develop advanced neuroblastoma with bone marrow metastasis. Cancer Res. 2013;73(13):4086-97.

46. Yogev O, Barker K, Sikka A, Almeida GS, Hallsworth A, Smith LM, Jamin Y, Ruddle R, Koers A, Webber HT, et al. p53 Loss in MYC-driven neuroblastoma leads to metabolic adaptations supporting radioresistance. Cancer Res. 2016; 76(10):3025-35.
47. Heukamp LC, Thor T, Schramm A, De Preter K, Kumps C, De Wilde B, Odersky A, Peifer M, Lindner S, Spruessel A, et al. Targeted expression of mutated ALK induces neuroblastoma in transgenic mice. Sci Transl Med. 2012:4(141):ARTN 141ra91.

48. Berry T, Luther W, Bhatnagar N, Jamin Y, Poon E, Sanda T, Pei D, Sharma B, Vetharoy WR, Hallsworth A, et al. The ALK(F1174 L) mutation potentiates the oncogenic activity of MYCN in neuroblastoma. Cancer Cell. 2012;22(1):117-30.

49. Iwakura H, Ariyasu H, Kanamoto N, Hosod K, Naka K, Kangawa K, Akamizu T. Establishment of a novel neuroblastoma mouse model. Int J Oncol. 2008; 33(6):1195-9. https://doi.org/10.3892/ijo_00000109.

50. Hattori Y, Kanamoto N, Kawano K, Iwakura H, Sone M, Miura M, Yasoda A, Tamura N, Arai H, Akamizu T, et al. Molecular characterization of tumors from a transgenic mouse adrenal tumor model: Comparison with human pheochromocytoma. Int J Oncol. 2010;37(3):695-705. https://doi.org/10. 3892/ijo_00000719.

51. Servenius B, Vernachio J, Price J, Andersson LC, Peterson PA. Metastasizing neuroblastomas in mice transgenic for simian-virus-40 large-T (SV40T) under the olfactory marker protein gene promoter. Cancer Res. 1994;54(19):5198-205.

52. Teitz T, Stanke JJ, Federico S, Bradley CL, Brennan R, Zhang JK, Johnson MD, Sedlacik J, Inoue M, Zhang ZWM, et al. Preclinical models for neuroblastoma: Establishing a baseline for treatment. Plos One. 2011;6(4): ARTN e19133.

53. Althoff K, Beckers A, Bell E, Nortmeyer M, Thor T, Sprussel A, Lindner S, De Preter K, Florin A, Heukamp LC, et al. A Cre-conditional MYCN-driven neuroblastoma mouse model as an improved tool for preclinical studies. Oncogene. 2015;34(26):3357-68. https://doi.org/10.1038/onc.2014.269.

54. Javanmardi N, Fransson S, Djos A, Sjoberg RM, Nilsson S, Truve K, Kogner P, Martinsson T. Low frequency ALK hotspots mutations in neuroblastoma tumours detected by ultra-deep sequencing: Implications for ALK inhibitor treatment. Sci Rep. 2019;9(1):2199.

55. Alvarado CS, London WB, Look AT, Brodeur GM, Altmiller DH, Thorner PS, Joshi W, Rowe ST, Nash MB, Smith El, et al. Natural history and biology of stage A neuroblastoma: a Pediatric Oncology Group Study. J Pediatr Hematol Oncol. 2000;22(3):197-205.

56. Guan J, Tucker ER, Wan H, Chand D, Danielson LS, Ruuth K, El Wakil A, Witek B, Jamin Y, Umapathy G, et al. The ALK inhibitor PF-06463922 is effective as a single agent in neuroblastoma driven by expression of ALK and MYCN. Dis Model Mech. 2016;9(9):941-52. https://doi.org/10.1242/dmm.024448.

57. Perel P, Roberts I, Sena E, Wheble P, Briscoe C, Sandercock P, Macleod M, Mignini LE, Jayaram P, Khan KS. Comparison of treatment effects between animal experiments and clinical trials: systematic review. Bmj-Brit Med J. 2007;334(7586):197-200. https://doi.org/10.1136/bmj.39048.407928.BE.

58. Kroesen M, Brok IC, Reijnen D, van Hout-Kuijer MA, Zeelenberg IS, Den Brok $\mathrm{MH}$, Hoogerbrugge PM, Adema GJ. Intra-adrenal murine TH-MYCN neuroblastoma tumors grow more aggressive and exhibit a distinct tumor microenvironment relative to their subcutaneous equivalents. Cancer Immunol Immunother. 2015;64(5):563-72. https://doi.org/10.1007/s00262015-1663-y.

59. Kroesen M, Nierkens S, Ansems M, Wassink M, Orentas RJ, Boon L, den Brok $\mathrm{MH}$, Hoogerbrugge PM, Adema GJ. A transplantable TH-MYCN transgenic tumor model in C57BI/6 mice for preclinical immunological studies in neuroblastoma. Int J Cancer. 2014;134(6):1335-45. https://doi.org/10.1002/ijc. 28463.

60. Cheng AJ, Cheng NC, Ford J, Smith J, Murray JE, Flemming C, Lastowska M, Jackson MS, Hackett CS, Weiss WA, et al. Cell lines from MYCN transgenic murine turnours reflect the molecular and biological characteristics of human neuroblastorna. Eur J Cancer. 2007:43(9):1467-75. https://doi.org/10. 1016/j.ejca.2007.03.008.

61. Tsubota S, Kishida S, Shimamura T, Ohira M, Yamashita S, Cao D, Kiyonari S, Ushijima T, Kadomatsu K. PRC2-mediated transcriptomic alterations at the embryonic stage govern tumorigenesis and clinical outcome in MYCNdriven neuroblastoma. Cancer Res. 2017;77(19):5259-71. https://doi.org/10. 1158/0008-5472.CAN-16-3144.

62. Davidoff AM, Kimbrough SA, Ng CYC, Shochat SJ, Vanin EF. Neuroblastoma regression and immunity induced by transgenic expression of interleukin12. J Pediatr Surg. 1999;34(5):902-6. https://doi.org/10.1016/S00223468(99)90395-0.

63. Shimizu T, Berhanu A, Redlinger RE Jr, Watkins S, Lotze MT, Barksdale EM Jr. Interleukin-12 transduced dendritic cells induce regression of established murine neuroblastoma. J Pediatr Surg. 2001;36(8):1285-92. https://doi.org/ 10.1053/jpsu.2001.25796. 
64. Lode HN, Xiang R, Varki NM, Dolman CS, Gillies SD, Reisfeld RA. Targeted interleukin-2 therapy for spontaneous neuroblastoma metastases to bone marrow. J Natl Cancer Inst. 1997;89(21):1586-94.

65. Inoue S, Setoyama Y, Odaka A, Kitagawa D, Beck Y. Chemoimmunotherapeutic effect of combined treatment with ex vivo generated antigen-presenting immune cells and conventional antitumor agents in a mouse neuroblastoma model. J Pediatr Surg. 2017;52(10):164250. https://doi.org/10.1016/j.jpedsurg.2017.04.006.

66. Bauer DF, Pereboeva L, Gillespie GY, Cloud GA, Elzafarany O, Langford C, Markert J, Lamb LS. Effect of HSV-IL12 loaded tumor cell-based vaccination in a mouse model of high-grade neuroblastoma. J Immunol Res. 2016:Artn 2568125. https://doi.org/10.1155/2016/2568125.

67. Jing W, Gershan JA, Johnson BD. Depletion of CD4 T cells enhances immunotherapy for neuroblastoma after syngeneic HSCT but compromises development of antitumor immune memory. Blood. 2009:113(18):4449-57. https://doi.org/10.1182/blood-2008-11-190827.

68. Rigo V, Emionite L, Daga A, Astigiano S, Corrias MV, Quintarelli C, Locatelli F, Ferrini S, Croce M. Combined immunotherapy with anti-PDL-1/PD-1 and anti-CD4 antibodies cures syngeneic disseminated neuroblastoma. Sci Rep. 2017;7(1):14049. https://doi.org/10.1038/s41598-017-14,417-6.

69. Chiu B, Coburn J, Pilichowska M, Holcroft C, Seib FP, Charest A, Kaplan DL. Surgery combined with controlled-release doxorubicin silk films as a treatment strategy in an orthotopic neuroblastoma mouse model. Brit J Cancer. 2014;111(4):708-15. https://doi.org/10.1038/bjc.2014.324.

70. Zhang L, Wu B, Baruchel S. Oral metronomic topotecan sensitizes crizotinib antitumor activity in ALK(F1174 L) drug-resistant neuroblastoma preclinical models. Transl Oncol. 2017;10(4):604-11. https://doi.org/10.1016/j.tranon. 2017.04.008

71. Valentiner U, Valentiner FU, Schumacher U. Expression of CD44 is associated with a metastatic pattern of human neuroblastoma cells in a SCID mouse xenograft model. Tumor Biol. 2008;29(3):152-60.

72. Zeki J, Taylor JS, Yavuz B, Coburn J, Ikegaki N, Kaplan DL, Chiu B. Disseminated injection of vincristine-loaded silk gel improves the suppression of neuroblastoma tumor growth. Surgery. 2018;164(4):909-15. https://doi.org/10.1016/j.surg.2018.06.017.

73. Coburn JM, Harris J, Cunningham R, Zeki J, Kaplan DL, Chiu B. Manipulation of variables in local controlled release vincristine treatment in neuroblastoma. J Pediatr Surg. 2017;52(12):2061-5. https://doi.org/10.1016/j. jpedsurg.2017.08.028.

74. Yavuz B, Zeki J, Coburn JM, Ikegaki N, Levitin D, Kaplan DL, Chiu B. In vitro and in vivo evaluation of etoposide - silk wafers for neuroblastoma treatment. J Control Release. 2018;285:162-71. https://doi.org/10.1016/j. jconrel.2018.07.002.

75. More SS, Itsara M, Yang XD, Geier EG, Tadano MK, Seo Y, VanBrocklin HF, Weiss WA, Mueller S, Haas-Kogan DA, et al. Vorinostat increases expression of functional norepinephrine transporter in neuroblastoma in vitro and in vivo model systems. Clin Cancer Res. 2011;17(8):2339-49. https://doi.org/10.1158/1078-0432.Ccr-10-2949

76. Takeuchi Y, Tanaka T, Higashi M, Fumino S, lehara T, Hosoi H, Sakai T, Tajiri T. In vivo effects of short- and long-term MAPK pathway inhibition against neuroblastoma. J Pediatr Surg. 2018;53(12):2454-9. https://doi.org/10.1016/j. jpedsurg.2018.08.026.

77. Wyce A, Ganji G, Smitheman KN, Chung CW, Korenchuk S, Bai YC Barbash O, Le BC, Craggs PD, McCabe MT, et al. BET inhibition silences expression of MYCN and BCL2 and induces cytotoxicity in neuroblastoma tumor models. Plos One. 2013;8(8):UNSP e72967. https:// doi.org/10.1371/journal.pone.0072967.

78. Ikegaki N, Shimada H, Fox AM, Regan PL, Jacobs JR, Hicks SL, Rappaport EF, Tang XX. Transient treatment with epigenetic modifiers yields stable neuroblastoma stem cells resembling aggressive large-cell neuroblastomas. P Natl Acad Sci USA. 2013;110(15):6097-102. https://doi.org/10.1073/pnas. 1118262110

79. Zins K, Kovatchki D, Lucas T, Abraham D. PIGF and VEGF-A regulate growth of high-risk MYCN-single copy neuroblastoma xenografts via different mechanisms. Int J Mol Sci. 2016;17(10):ARTN 1613. https://doi.org/10.3390/ijms17101613.

80. Beaudry P, Campbell M, Dang NH, Wen J, Blote K, Weljie AM. A pilot study on the utility of serum metabolomics in neuroblastoma patients and xenograft models. Pediatr Blood Cancer. 2016;63(2):214-20. https://doi.org/ 10.1002/pbc.25784 .

81. Harris J, Herrero-Garcia E, Russo A, Kajdacsy-Balla A, O'Bryan JP, Chiu B. Silencing intersectin 1 slows orthotopic neuroblastoma growth in mice. J
Pediat Hematol Onc. 2017;39(8):E413-8. https://doi.org/10.1097/Mph. 0000000000000931.

82. Lin LL, Huang CC, Wu CL, Wu MT, Hsu WM, Chuang JH. Downregulation of c-Myc is involved in TLR3-mediated tumor death of neuroblastoma xenografts. Lab Invest. 2016;96(7):719-30. https://doi.org/10.1038/labinvest. 2016.57.

83. Hartwich J, Orr WS, Ng CY, Spence Y, Morton C, Davidoff AM. HIF-1 alpha activation mediates resistance to anti-angiogenic therapy in neuroblastoma xenografts. J Pediatr Surg. 2013;48(1):39-46. https://doi.org/10.1016/j. jpedsurg.2012.10.016.

84. Zins K, Schafer R, Paulus P, Dobler S, Fakhari N, Sioud M, Aharinejad S, Abraham D. Frizzled2 signaling regulates growth of high-risk neuroblastomas by interfering with beta-catenin-dependent and betacatenin-independent signaling pathways. Oncotarget. 2016;7(29):46187-202. https://doi.org/10.18632/oncotarget.10070.

85. Huang CC, Wang SY, Lin LL, Wang PW, Chen TY, Hsu WM, Lin TK, Liou CW, Chuang JH. Glycolytic inhibitor 2-deoxyglucose simultaneously targets cancer and endothelial cells to suppress neuroblastoma growth in mice. Dis Model Mech. 2015;8(10):1247-54. https://doi.org/10.1242/dmm.021667.

86. Swift L, Zhang CF, Trippett T, Narendran A. Potent in vitro and xenograft antitumor activity of a novel agent, PV-10, against relapsed and refractory neuroblastoma. Oncotargets Ther. 2019;12:1293-307. https://doi.org/10. 2147/Ott.S191478.

87. Sun W, Rojas Y, Wang H, Yu Y, Wang Y, Chen Z, Rajapakshe K, Xu X, Huang W, Agarwal S, et al. EWS-FLI1 and RNA helicase A interaction inhibitor YK-4279 inhibits growth of neuroblastoma. Oncotarget. 2017;8(55):94780-92. https://doi.org/10.18632/oncotarget.21933.

88. Nguyen F, Alferiev I, Guan P, Guerrero DT, Kolla V, Moorthy GS, Chorny M, Brodeur GM. Enhanced intratumoral delivery of SN38 as a tocopherol oxyacetate prodrug using nanoparticles in a neuroblastoma xenograft model. Clin Cancer Res. 2018;24(11):2585-93. https://doi.org/10.1158/10780432. Ccr-17-3811.

89. Evans AE, Kisselbach KD, Yamashiro DJ, Ikegaki N, Camoratto AM, Dionne CA, Brodeur GM. Antitumor activity of CEP-751 (KT-6587) on human neuroblastoma and medulloblastoma xenografts. Clin Cancer Res. 1999;5(11):3594-602.

90. Daudigeos-Dubus E, Le Dret L, Bawa O, Opolon P, Vievard A, Villa I, Bosq J, Vassal G, Geoerger B. Dual inhibition using cabozantinib overcomes HGF/ MET signaling mediated resistance to pan-VEGFR inhibition in orthotopic and metastatic neuroblastoma tumors. Int J Oncol. 2017;50(1):203-11. https://doi.org/10.3892/ijo.2016.3792.

91. Daudigeos-Dubus E, Le Dret L, Rouffiac V, Bawa O, Leguerney I, Opolon P, Vassal G, Geoerger B. Establishment and characterization of new orthotopic and metastatic neuroblastoma models. In Vivo. 2014;28(4):425-34.

92. Henssen AG, Odersky A, Szymansky A, Seiler M, Althoff K, Beckers A, Speleman F, Schafers S, De Preter K, Astrahanseff K, et al. Targeting tachykinin receptors in neuroblastoma. Oncotarget. 2017:8(1):430-43. https://doi.org/10.18632/oncotarget.13440.

93. Feng C, Wang TY, Tang RH, Wang JW, Long H, Gao XN, Tang SQ. Silencing of the MYCN gene by siRNA delivered by folate receptor-targeted liposomes in LA-N-5 cells. Pediatr Surg Int. 2010;26(12):1185-91. https://doi. org/10.1007/s00383-010-2703-5.

94. Zhu QQ, Feng C, Liao WW, Zhang Y, Tang SQ. Target delivery of MYCN siRNA by folate-nanoliposomes delivery system in a metastatic neuroblastoma model. Cancer Cell Int. 2013;13:Artn 65. https://doi.org/10. 1186/1475-2867-13-65.

95. Ryu S, Hayashi M, Aikawa H, Okamoto I, Fujiwara Y, Hamada A. Heterogeneous distribution of alectinib in neuroblastoma xenografts revealed by matrix-assisted laser desorption ionization mass spectrometry imaging: a pilot study. Brit J Pharmacol. 2018;175(1):29-37. https://doi.org/ 10.1111/bph.14067.

96. Nomura M, Shimbo T, Miyamoto Y, Fukuzawa M, Kaneda Y. 13-Cis retinoic acid can enhance the antitumor activity of non-replicating Sendai virus particle against neuroblastoma. Cancer Sci. 2013;104(2):238-44. https://doi. org/10.1111/cas.12063.

97. Yao PL, Chen LP, Dobrzanski TP, Zhu BK, Kang BH, Muller R, Gonzalez FJ, Peters JM. Peroxisome proliferator-activated receptor-beta/delta inhibits human neuroblastoma cell tumorigenesis by inducing p53-and SOX2mediated cell differentiation. Mol Carcinogen. 2017;56(5):1472-83. https:// doi.org/10.1002/mc.22607.

98. Shusterman S, Grupp SA, Barr R, Carpentieri D, Zhao HQ, Maris JM. The angiogenesis inhibitor TNP-470 effectively inhibits human neuroblastoma 
xenograft growth, especially in the setting of subclinical disease. Clin Cancer Res. 2001;7(4):977-84.

99. Morowitz MJ, Barr R, Wang Q, King R, Rhodin N, Pawel B, Zhao HQ, Erickson SA, Sheppard GS, Wang JY, et al. Methionine aminopeptidase 2 inhibition is an effective treatment strategy for neuroblastoma in preclinical models. Clin Cancer Res. 2005;11(7):2680-5. https://doi.org/10.1158/1078-0432.Ccr-041917.

100. Zamboni WC, Houghton PJ, Thompson J, Cheshire PJ, Hanna SK, Richmond LB, Lou XL, Stewart CF. Altered irinotecan and SN-38 disposition after intravenous and oral administration of irinotecan in mice bearing human neuroblastoma xenografts. Clin Cancer Res. 1998;4(2):455-62.

101. Thompson J, Zamboni WC, Cheshire PJ, Lutz L, Luo XL, Li YL, Houghton JA, Stewart CF, Houghton PJ. Efficacy of systemic administration of irinotecan against neuroblastoma xenografts. Clin Cancer Res. 1997;3(3):423-31.

102. Odate S, Veschi V, Yan S, Lam N, Woessner R, Thiele CJ. Inhibition of STAT3 with the generation 2.5 antisense oligonucleotide, AZD9150, decreases neuroblastoma tumorigenicity and increases chemosensitivity. Clin Cancer Res. 2017;23(7):1771-84. https://doi.org/10.1158/1078-0432.Ccr-16-1317.

103. Corroyer-Dulmont A, Falzone N, Kersemans V, Thompson J, Allen DP, Able S, Kartsonaki C, Malcolm J, Kinchesh P, Hill MA, et al. Improved outcome of I131-mIBG treatment through combination with external beam radiotherapy in the SK-N-SH mouse model of neuroblastoma. Radiother Oncol. 2017; 124(3):488-95. https://doi.org/10.1016/.radonc.2017.05.002.

104. Jani A, Shaikh F, Barton S, Willis C, Banerjee D, Mitchell J, Hernandez SL, Hei T, Kadenhe-Chiweshe A, Yamashiro DJ, et al. High-dose, single-fraction irradiation rapidly reduces tumor vasculature and perfusion in a xenograft model of neuroblastoma. Int J Radiat Oncol. 2016;94(5):1173-80. https://doi. org/10.1016/j.jrobp.2015.12.367.

105. Byrne FL, Yang L, Phillips PA, Hansford LM, Fletcher Jl, Ormandy CJ, McCarroll JA, Kavallaris M. RNAi-mediated stathmin suppression reduces lung metastasis in an orthotopic neuroblastoma mouse model. Oncogene. 2014;33(7):882-90. https://doi.org/10.1038/onc.2013.11.

106. Iyer R, Croucher JL, Chorny M, Mangino JL, Alferiev IS, Levy RJ, Kolla V, Brodeur GM. Nanoparticle delivery of an SN38 conjugate is more effective than Irinotecan in a mouse model of Neuroblastoma. Cancer Res. 2015;75. https://doi.org/10.1158/1538-7445.Am2015-5537.

107. Yang C, Tan J, Zhu J, Wang S, Wei GH. YAP promotes tumorigenesis and cisplatin resistance in neuroblastoma. Oncotarget. 2017;8(23):37154-63. https://doi.org/10.18632/oncotarget.16209.

108. Wang HQ, Halilovic E, Li XY, Liang JS, Cao YC, Rakiec DP, Ruddy DA, Jeay S, Wuerthner JU, Timple N, et al. Combined ALK and MDM2 inhibition increases antitumor activity and overcomes resistance in human ALK mutant neuroblastoma cell lines and xenograft models. Elife. 2017;6:ARTN e17137. https://doi.org/10.7554/eLife.17137.

109. Seong BKA, Fathers KE, Hallett R, Yung CK, Stein LD, Mouaaz S, Kee L, Hawkins CE, Irwin MS, Kaplan DR. A metastatic mouse model identifies genes that regulate neuroblastoma metastasis. Cancer Res. 2017;77(3):696706. https://doi.org/10.1158/0008-5472.Can-16-1502 .

110. Borriello L, Nakata R, Sheard MA, Fernandez GE, Sposto R, Malvar J, Blavier L, Shimada H, Asgharzadeh S, Seeger RC, et al. Cancer-Associated Fibroblasts Share Characteristics and Protumorigenic Activity with Mesenchymal Stromal Cells. Cancer Res. 2017;77(18):5142-57. https://doi.org/10.1158/00085472.Can-16-2586.

111. Fang CY, Wu CC, Fang CL, Chen WY, Chen CL. Long-term growth comparison studies of FBS and FBS alternatives in six head and neck cell lines. PLoS One. 2017;12(6):e0178960. https://doi.org/10.1371/journal.pone.0178960.

112. Lee J, Kotliarova S, Kotliarov Y, Li A, Su Q, Donin NM, Pastorino S, Purow BW, Christopher N, Zhang W, et al. Tumor stem cells derived from glioblastomas cultured in bFGF and EGF more closely mirror the phenotype and genotype of primary tumors than do serum-cultured cell lines. Cancer Cell. 2006;9(5): 391-403. https://doi.org/10.1016/j.ccr.2006.03.030.

113. Gillet JP, Calcagno AM, Varma S, Marino M, Green L, Vora MI, Patel C, Orina $\mathrm{JN}$, Eliseeva TA, Singal V, et al. Redefining the relevance of established cancer cell lines to the study of mechanisms of clinical anti-cancer drug resistance. Proc Natl Acad Sci U S A. 2011;108(46):18708-18,713. https://doi. org/10.1073/pnas. 1111840108.

114. Braekeveldt N, Wigerup C, Gisselsson D, Mohlin S, Merselius M, Beckman S, Jonson T, Borjesson A, Backman T, Tadeo I, et al. Neuroblastoma patientderived orthotopic xenografts retain metastatic patterns and geno- and phenotypes of patient tumours. Int J Cancer. 2015;136(5):E252-61. https:// doi.org/10.1002/ijc.29217.
115. Stewart E, Shelat A, Bradley C, Chen X, Federico S, Thiagarajan S, Shirinifard A, Bahrami A, Pappo A, Qu CX, et al. Development and characterization of a human orthotopic neuroblastoma xenograft. Dev Biol. 2015;407(2):344-55. https://doi.org/10.1016/j.ydbio.2015.02.002.

116. Braekeveldt N, Wigerup C, Tadeo I, Beckman S, Sanden C, Jonsson J, Erjefalt JS, Berbegall AP, Borjesson A, Backman T, et al. Neuroblastoma patientderived orthotopic xenografts reflect the microenvironmental hallmarks of aggressive patient tumours. Cancer Lett. 2016;375(2):384-9. https://doi.org/ 10.1016/j.canlet.2016.02.046.

117. Gao Q, Chen CF, Dong Q, Hou L, Chen X, Zhi YL, Li X, Lu HT, Zhang HY. Establishment of a neuroblastoma mouse model by subcutaneous xenograft transplantation and its use to study metastatic neuroblastoma. Genet Mol Res. 2015;14(4):16297-16,307. https://doi.org/10.4238/2015. December.8.20.

118. Bate-Eya LT, Ebus ME, Koster J, den Hartog IJM, Zwijnenburg DA, Schild L, van der Ploeg I, Dolman MEM, Caron HN, Versteeg R, et al. Newly-derived neuroblastoma cell lines propagated in serum-free media recapitulate the genotype and phenotype of primary neuroblastoma tumours. Eur J Cancer. 2014;50(3):628-37. https://doi.org/10.1016/j.ejca.2013.11.015.

119. Hidalgo M, Bruckheimer E, Rajeshkumar NV, Garrido-Laguna I, De Oliveira E, Rubio-Viqueira B, Strawn S, Wick MJ, Martell J, Sidransky D. A pilot clinical study of treatment guided by personalized tumorgrafts in patients with advanced cancer. Mol Cancer Ther. 2011;10(8):1311-6. https://doi.org/10. 1158/1535-7163.MCT-11-0233.

120. Bankert RB, Balu-lyer SV, Odunsi K, Shultz LD, Kelleher RJ Jr, Barnas JL, Simpson-Abelson M, Parsons R, Yokota SJ. Humanized mouse model of ovarian cancer recapitulates patient solid tumor progression, ascites formation, and metastasis. PLoS One. 2011;6(9):e24420. https://doi.org/10. 1371/journal.pone.0024420.

121. Shultz LD, Lyons BL, Burzenski LM, Gott B, Chen X, Chaleff S, Kotb M, Gillies SD, King M, Mangada J, et al. Human lymphoid and myeloid cell development in NOD/LtSz-scid IL2R gamma null mice engrafted with mobilized human hemopoietic stem cells. J Immunol. 2005;174(10):6477-89.

122. McIntosh BE, Brown ME, Duffin BM, Maufort JP, Vereide DT, Slukvin II, Thomson JA. Nonirradiated NOD,B6.SCID II2r gamma(-/-) Kit(W41/W41) (NBSGW) Mice Support Multilineage Engraftment of Human Hematopoietic Cells. Stem Cell Rep. 2015;4(2):171-80. https://doi.org/10.1016/j.stemcr.2014. 12.005 .

123. Theocharides APA, Rongvaux A, Fritsch K, Flavell RA, Manz MG. Humanized hemato-lymphoid system mice. Haematologica. 2016;101(1):5-19. https:// doi.org/10.3324/haematol.2014.115212.

124. Wang H, La Russa M, Qi LS. CRISPR/Cas9 in genome editing and beyond. Annu Rev Biochem. 2016;85:227-64. https://doi.org/10.1146/annurevbiochem-060815-014607.

125. Calos MP. Genome editing techniques and their therapeutic applications. Clin Pharmacol Ther. 2017;101(1):42-51. https://doi.org/10.1002/cpt.542.

126. Yin H, Kauffman KJ, Anderson DG. Delivery technologies for genome editing. Nat Rev Drug Discov. 2017;16(6):387-99. https://doi.org/10.1038/nrd. 2016.280.

127. Park JH, Szemes M, Vieira GC, Melegh Z, Malik S, Heesom KJ, Von WallwitzFreitas $L$, Greenhough A, Brown KW, Zheng YG, et al. Protein arginine methyltransferase 5 is a key regulator of the MYCN oncoprotein in neuroblastoma cells. Mol Oncol. 2015;9(3):617-27. https://doi.org/10.1016/j. molonc.2014.10.015.

128. Ambrosio S, Amente S, Sacca CD, Capasso M, Calogero RA, Lania L, Majello B. LSD1 mediates MYCN control of epithelial-mesenchymal transition through silencing of metastatic suppressor NDRG1 gene. Oncotarget. 2017; 8(3):3854-69. https://doi.org/10.18632/oncotarget.12924.

129. Shen J, Najafi S, Stable S, Fabian J, Koeneke E, Kolbinger FR, Wrobel JK, Meder B, Distel M, Heimburg T, et al. A kinome-wide RNAi screen identifies ALK as a target to sensitize neuroblastoma cells for HDAC8-inhibitor treatment. Cell Death Differ. 2018;25(12):2053-70. https://doi.org/10.1038/ s41418-018-0080-0.

130. Chen L, Alexe G, Dharia NV, Ross L, Iniguez AB, Conway AS, Wang EJ, Veschi V, Lam N, Qi J, et al. CRISPR-Cas9 screen reveals a MYCN-amplified neuroblastoma dependency on EZH2. J Clin Invest. 2018;128(1):446-62. https://doi.org/10.1172/JCl90793.

131. Mahoney CE, Pirman D, Chubukov V, Sleger T, Hayes S, Fan ZP, Allen EL, Chen $Y$, Huang L, Liu M, et al. A chemical biology screen identifies a vulnerability of neuroendocrine cancer cells to SQLE inhibition. Nat Commun. 2019;10(1):96. https://doi.org/10.1038/s41467-018-07959-4. 
132. Michaelis M, Agha B, Rothweiler F, Loschmann N, Voges Y, Mittelbronn M, Starzetz T, Harter PN, Abhari BA, Fulda S, et al. Identification of flubendazole as potential anti-neuroblastoma compound in a large cell line screen. Sci Rep Uk. 2015;5. https://doi.org/10.1038/srep08202.

133. Hashimoto O, Yoshida M, Koma Yl, Yanai T, Hasegawa D, Kosaka Y, Nishimura N, Yokozaki H. Collaboration of cancer-associated fibroblasts and tumour-associated macrophages for neuroblastoma development. J Pathol. 2016;240(2):211-23. https://doi.org/10.1002/path.4769.

134. Rizvanov AA, Yalvac ME, Shafigullina AK, Salafutdinov II, Blatt NL, Sahin F, Kiyasov AP, Palotas A. Interaction and self-organization of human mesenchymal stem cells and neuro-blastoma SH-SY5Y cells under coculture conditions: A novel system for modeling cancer cell microenvironment. Eur J Pharm Biopharm. 2010;76(2):253-9. https://doi.org/10. 1016/j.ejpb.2010.05.012.

135. Terme M, Dorvillius M, Cochonneau D, Chaumette T, Xiao W. Chimeric antibody c.8B6 to O-Acetyl-GD2 mediates the same efficient antineuroblastoma effects as therapeutic ch14.18 antibody to GD2 without antibody induced allodynia (vol 9, e87210, 2014). Plos One. 2014;9(7):ARTN e103395. https://doi.org/10.1371/journal.pone.0103395.

136. Siebert N, Zumpe M, Juttner M, Troschke-Meurer S, Lode HN. PD-1 blockade augments anti-neuroblastoma immune response induced by anti-GD(2) antibody ch14.18/CHO. Oncoimmunology. 2017;6(10):ARTN e1343775. https://doi.org/10.1080/2162402X.2017.1343775.

137. Batova A, Kamps A, Gillies SD, Reisfeld RA, Yu AL. The Ch14.18-GM-CSF fusion protein is effective at mediating antibody-dependent cellular cytotoxicity and complement-dependent cytotoxicity in vitro. Clin Cancer Res. 1999;5(12):4259-63.

138. Shibina A, Seidel D, Somanchi SS, Lee DA, Stermann A, Maurer BJ, Lode HN, Reynolds CP, Huebener N. Fenretinide sensitizes multidrug-resistant human neuroblastoma cells to antibody-independent and ch14.18-mediated NK cell cytotoxicity. J Mol Med. 2013;91(4):459-72. https://doi.org/10.1007/ s00109-012-0958-0.

139. Fukuda M, Horibe K, Furukawa K. Enhancement of in vitro and in vivo antitumor activity of anti-GD2 monoclonal antibody 220-51 against human neuroblastoma by granulocyte-macrophage colony-stimulating factor and granulocyte colony-stimulating factor. Int J Mol Med. 1998;2(4):471-5.

140. Beierle EA, Dai W, Langham MR, Copeland EM, Chen MK. Expression of VEGF receptors in cocultured neuroblastoma cells. J Surg Res. 2004;119(1):56-65. https://doi.org/10.1016/j.jss.2004.01.002.

141. Chen MK, Strande L, Kain M, Whalen TV, Doolin EJ. Induction of apoptosis in a neuroblastoma and hepatocyte coculture model. J Surg Res. 1998;78(2): 123-30. https://doi.org/10.1006/jsre.1998.5363.

142. Chanthery YH, Gustafson WC, Itsara M, Persson A, Hackett CS, Grimmer M, Charron E, Yakovenko S, Kim G, Matthay KK, et al. Paracrine signaling through MYCN enhances tumor-vascular interactions in neuroblastoma. Sci Transl Med. 2012;4(115):ARTN 115ra3. https://doi.org/10.1126/scitranslmed. 3002977.

143. Poliani PL, Mitola S, Ravanini M, Ferrari-Toninelli G, D'Ippolito C, Notarangelo LD, Bercich L, Wagener C, Memo M, Presta M, et al. CEACAM1/NEGF crosstalk during neuroblastic tumour differentiation. J Pathol. 2007;211(5):541-9. https://doi.org/10.1002/path.2135.

144. Baek N, Seo OW, Kim M, Hulme J, An SSA. Monitoring the effects of doxorubicin on 3D-spheroid tumor cells in real-time. Oncotargets Ther. 2016;9:7207-18. https://doi.org/10.2147/Ott.S112566.

145. Chikaraishi K, Takenobu H, Sugino RP, Mukae K, Akter J, Haruta M, Kurosumi M, Endo TA, Koseki H, Shimojo N, et al. CFC1 is a cancer stemnessregulating factor in neuroblastoma. Oncotarget. 2017;8(28):45046-45,059.

146. Gransbury GK, Kappen P, Glover CJ, Hughes JN, Levina A, Lay PA, Musgrave IF, Harris HH. Comparison of KP1019 and NAMI-A in tumour-mimetic environments. Metallomics. 2016;8(8):762-73. https://doi.org/10.1039/ c6mt00145a.

147. Griner LM, Gampa K, Do T, Nguyen H, Farley D, Hogan CJ, Auld DS, Silver SJ. Generation of high-throughput three-dimensional tumor spheroids for drug screening. J Vis Exp. 2018;139. https://doi.org/10.3791/57476.

148. Kumar HR, Zhong X, Hoelz DJ, Rescorla FJ, Hickey RJ, Malkas LH, Sandoval JA. Three-dimensional neuroblastoma cell culture: proteomic analysis between monolayer and multicellular tumor spheroids. Pediatr Surg Int. 2008:24(11):1229-34. https://doi.org/10.1007/s00383-008-2245-2.

149. Sidarovich V, De Mariano M, Aveic S, Pancher M, Adami V, Gatto P, Pizzini S, Pasini L, Croce M, Parodi F, et al. A high-content screening of anticancer compounds suggests the multiple tyrosine kinase inhibitor ponatinib for repurposing in neuroblastoma therapy. Mol Cancer Ther. 2018;17(7):140515. https://doi.org/10.1158/1535-7163.MCT-17-0841.

150. Hansford LM, McKee AE, Zhang L, George RE, Gerstle JT, Thorner PS, Smith KM, Look AT, Yeger $\mathrm{H}$, Miller FD, et al. Neuroblastoma cells isolated from bone marrow metastases contain a naturally enriched tumor-initiating cell. Cancer Res. 2007;67(23):11234-11,243. https://doi.org/10.1158/0008-5472. CAN-07-0718.

151. Coulon A, Flahaut M, Muhlethaler-Mottet A, Meier R, Liberman J, BalmasBourloud K, Nardou K, Yan P, Tercier S, Joseph JM, et al. Functional sphere profiling reveals the complexity of neuroblastoma tumor-initiating cell model. Neoplasia. 2011;13(10):991-1004.

152. Suebsoonthron J, Jaroonwitchawan T, Yamabhai M, Noisa P. Inhibition of WNT signaling reduces differentiation and induces sensitivity to doxorubicin in human malignant neuroblastoma SH-SY5Y cells. Anticancer Drugs. 2017; 28(5):469-79. https://doi.org/10.1097/CAD.0000000000000478.

153. Ayla S, Bilir A, Soner BC, Yilmaz-Dilsiz O, Erguven M, Oktem G. Notch signaling-related therapeutic strategies with novel drugs in neuroblastoma spheroids. J Pediatr Hematol Oncol. 2014;36(1):37-44. https://doi.org/10. 1097/MPH.0b013e3182755c73.

154. Craig BT, Rellinger EJ, Alvarez AL, Dusek HL, Qiao J, Chung DH. Induced differentiation inhibits sphere formation in neuroblastoma. Biochem Biophys Res Commun. 2016;477(2):255-9. https://doi.org/10.1016/j.bbrc.2016.06.053.

155. Cuperus R, van Kuilenburg AB, Leen R, Bras J, Caron HN, Tytgat GA. Promising effects of the $4 \mathrm{HPR}-\mathrm{BSO}$ combination in neuroblastoma monolayers and spheroids. Free Radic Biol Med. 2011;51(6):1213-20. https:// doi.org/10.1016/j.freeradbiomed.2011.06.019.

156. Sagnella SM, Trieu J, Brahmbhatt H, MacDiarmid JA, MacMillan A, Whan RM, Fife CM, McCarroll JA, Gifford AJ, Ziegler DS, et al. Targeted doxorubicinloaded bacterially derived nano-cells for the treatment of neuroblastoma. Mol Cancer Ther. 2018;17(5):1012-23. https://doi.org/10.1158/1535-7163. MCT-17-0738.

157. Cunningham SH, Mairs RJ, Wheldon TE, Welsh PC, Vaidyanathan G, Zalutsky MR. Toxicity to neuroblastoma cells and spheroids of benzylguanidine conjugated to radionuclides with short-range emissions. Br J Cancer. 1998; 77(12):2061-8.

158. Aveic S, Corallo D, Porcu E, Pantile M, Boso D, Zanon C, Viola G, Sidarovich V, Mariotto E, Quattrone A, et al. TP-0903 inhibits neuroblastoma cell growth and enhances the sensitivity to conventional chemotherapy. Eur J Pharmacol. 2018;818:435-48. https://doi.org/10.1016/j.ejphar.2017.11.016.

159. Navratilova J, Karasova M, Kohutkova Lanova M, Jirakova L, Budkova Z, Pachernik J, Smarda J, Benes P. Selective elimination of neuroblastoma cells by synergistic effect of Akt kinase inhibitor and tetrathiomolybdate. J Cell Mol Med. 2017;21(9):1859-69. https://doi.org/10.1111/jcmm.13106.

160. Lee JM, Park DY, Yang L, Kim EJ, Ahrberg CD, Lee KB, Chung BG. Generation of uniform-sized multicellular tumor spheroids using hydrogel microwells for advanced drug screening. Sci Rep. 2018;8(1):17145. https://doi.org/10. 1038/s41598-018-35,216-7.

161. Daster S, Amatruda N, Calabrese D, Ivanek R, Turrini E, Droeser RA, Zajac $P$ Fimognari C, Spagnoli GC, lezzi G, et al. Induction of hypoxia and necrosis in multicellular tumor spheroids is associated with resistance to chemotherapy treatment. Oncotarget. 2017;8(1):1725-36. https://doi.org/10. 18632/oncotarget.13857.

162. Hoffmann Ol, Ilmberger C, Magosch S, Joka M, Jauch KW, Mayer B. Impact of the spheroid model complexity on drug response. J Biotechnol. 2015;205: 14-23. https://doi.org/10.1016/j.jbiotec.2015.02.029.

163. Priwitaningrum DL, Blonde JG, Sridhar A, van Baarlen J, Hennink WE, Storm G, Le Gac S, Prakash J. Tumor stroma-containing 3D spheroid arrays: A tool to study nanoparticle penetration. J Control Release. 2016;244(Pt B):257-68. https://doi.org/10.1016/j.jconrel.2016.09.004.

164. Courau T, Bonnereau J, Chicoteau J, Bottois H, Remark R, Assante Miranda L, Toubert A, Blery M, Aparicio T, Allez M, et al. Cocultures of human colorectal tumor spheroids with immune cells reveal the therapeutic potential of MICA/B and NKG2A targeting for cancer treatment. J Immunother Cancer. 2019:7(1):74. https://doi.org/10.1186/s40425-019-0553-9.

165. Jung HR, Kang HM, Ryu JW, Kim DS, Noh KH, Kim ES, Lee HJ, Chung KS, Cho HS, Kim NS, et al. Cell spheroids with enhanced aggressiveness to mimic human liver cancer in vitro and in vivo. Sci Rep-Uk. 2017;7:1-14.

166. Li GN, Livi LL, Gourd CM, Deweerd ES, Hoffman-Kim D. Genomic and morphological changes of neuroblastoma cells in response to threedimensional matrices. Tissue Eng. 2007;13(5):1035-47. https://doi.org/10. 1089/ten.2006.0251. 
167. Mitchell CB, O'Neill GM: Cooperative cell invasion: matrix metalloproteinasemediated incorporation between cells. Mol Biol Cell 2016, 27(21):3284-3292. doi:https://doi.org/10.1091/mbc. E16-03-0194.

168. Mitchell CB, O'Neill GM. Rac GTPase regulation of 3D invasion in neuroblastomas lacking MYCN amplification. Cell Adh Migr. 2017;11(1):6879. https://doi.org/10.1080/19336918.2016.1183868.

169. Curtin C, Nolan JC, Conlon R, Deneweth L, Gallagher C, Tan YJ, Cavanagh BL, Asraf AZ, Harvey H, Miller-Delaney S, et al. A physiologically relevant 3D collagen-based scaffold-neuroblastoma cell system exhibits chemosensitivity similar to orthotopic xenograft models. Acta Biomater. 2018;70:84-97. https://doi.org/10.1016/j.actbio.2018.02.004.

170. Fitzgerald KA, Guo JF, Tierney EG, Curtin CM, Malhotra M, Darcy R, O'Brien FJ, O'Driscoll CM. The use of collagen-based scaffolds to simulate prostate cancer bone metastases with potential for evaluating delivery of nanoparticulate gene therapeutics. Biomaterials. 2015;66:53-66. https://doi. org/10.1016/j.biomaterials.2015.07.019.

171. Stock K, Estrada MF, Vidic S, Gjerde K, Rudisch A, Santo VE, Barbier M, Blom S, Arundkar SC, Selvam I, et al. Capturing tumor complexity in vitro: Comparative analysis of $2 \mathrm{D}$ and $3 \mathrm{D}$ tumor models for drug discovery. Sci Rep. 2016;6:28951. https://doi.org/10.1038/srep28951.

172. Kazantseva J, Ivanov R, Gasik M, Neuman T, Hussainova I. Grapheneaugmented nanofiber scaffolds trigger gene expression switching of four cancer cell types. ACS Biomater Sci Eng. 2018;4(5):1622-9. https://doi.org/10. 1021/acsbiomaterials.8b00228.

173. Mitra M, Mohanty C, Harilal A, Maheswari UK, Sahoo SK, Krishnakumar S. A novel in vitro three-dimensional retinoblastoma model for evaluating chemotherapeutic drugs. Mol Vis. 2012;18(142-45):1361-78.

174. Fong ELS, Lamhamedi-Cherradi SE, Burdett E, Ramamoorthy V, Lazar AJ, Kasper FK, Farach-Carson MC, Vishwamitra D, Demicco EG, Menegaz BA, et al. Modeling Ewing sarcoma tumors in vitro with 3D scaffolds. P Natl Acad Sci USA. 2013;1 10(16):6500-5. https://doi.org/10.1073/pnas. 1221403110

175. Marturano-Kruik A, Villasante A, Yaeger K, Ambati SR, Chramiec A, Raimondi MT, Vunjak-Novakovic G. Biomechanical regulation of drug sensitivity in an engineered model of human tumor. Biomaterials. 2018;150:150-61. https:// doi.org/10.1016/j.biomaterials.2017.10.020.

176. Villasante A, Sakaquchi K, Kim J, Cheung NK, Nakayama M, Parsa H, Okano T, Shimizu T, Vunjak-Novakovic G. Vascularized tissue-engineered model for studying drug resistance in neuroblastoma. Theranostics. 2017;7(17):4099117. https://doi.org/10.7150/thno.20730.

177. Yeung P, Sin HS, Chan S, Chan GCF, Chan BP. Microencapsulation of neuroblastoma cells and mesenchymal stromal cells in collagen microspheres: A 3D model for cancer cell niche study. Plos One. 2015; 10(12):ARTN e0144139. https://doi.org/10.1371/journal.pone.0144139.

178. Yeung CW, Cheah K, Chan D, Chan BP. Effects of reconstituted collagen matrix on fates of mouse embryonic stem cells before and after induction for chondrogenic differentiation. Tissue Eng Pt A. 2009;15(10):3071-85 https://doi.org/10.1089/ten.tea.2008.0661.

\section{Publisher's Note}

Springer Nature remains neutral with regard to jurisdictional claims in published maps and institutional affiliations.

Ready to submit your research? Choose BMC and benefit from:
- fast, convenient online submission
- thorough peer review by experienced researchers in your field
- rapid publication on acceptance
- support for research data, including large and complex data types
- gold Open Access which fosters wider collaboration and increased citations
- maximum visibility for your research: over 100M website views per year
At BMC, research is always in progress.
Learn more biomedcentral.com/submissions

